\author{
KS. RAFA£ KAMIŃSKI CSMA \\ Wydział Prawa Kanonicznego \\ Uniwersytetu Kardynała Stefana Wyszyńskiego w Warszawie \\ ORCID: 0000-0002-7822-3402
}

\title{
FORMA ZWYCZAJNA ZAWARCIA MAŁŻEŃSTWA KANONICZNEGO
}

Treść: Wstęp. - 1. Wymagania formy zwyczajnej zawarcia małżeństwa. 1.1. Świadek kwalifikowany z urzędu. - 1.2. Świadek kwalifikowany delegowany. - 1.2.1. Delegacja kapłana. - 1.2.2. Delegacja diakona. - 1.2.3. Delegacja wiernego świeckiego. - 1.3. Możliwość subdelegacji. - 1.4. Świadkowie zwykli. - 2. Znaczenie formy. - 3. Wymóg zastosowania formy kanonicznej. 4. Dyspensa. - Zakończenie.

\section{Wstęp}

Przyczyną sprawczą małżeństwa jest zgoda stron (kan. 1057 KPK). Ten akt woli, który strony wyrażają w celu jego zawarcia, jest w świetle prawa naturalnego wystarczający do zaistnienia ważnego małżeństwa. Kościół, traktując sposób wyrażenia zgody małżeńskiej jako kwestię drugorzędną, nie tworzył odrębnych przepisów, dostosowując się do zwyczajów panujących w poszczególnych krajach, na terenie których pełnił swoją misję. Aż do czasu Soboru Trydenckiego forma zawarcia małżeństwa nie była więc ujednolicona ${ }^{1}$.

\footnotetext{
${ }^{1}$ Por. S. Biskupski, Prawo małżeńskie Kościoła Rzymskokatolickiego, t. 1, Warszawa 1956, s. 320-324.
} 
Soborowy dekret Tametsi ${ }^{2}$ i jego trudności aplikacyjne w zakresie określenia właściwości proboszcza asystującego zawarciu małżeństwa, zrodziły potrzebę reformy, która zaowocowała wydaniem dnia 2 sierpnia 1907 r. dekretu Świętej Kongregacji Soboru Ne temere ${ }^{3}$. $\mathrm{W}$ zakresie formy zawarcia małżeństwa wyróżniono w nim formę zwyczajną, jako podstawową oraz formę nadzwyczajną, jako wyjątkowy sposób zawarcia małżeństwa.

Promulgowany dziesięć lat później Kodeks Prawa Kanonicznego z 1917 roku przejął postanowienia dekretu z niewielkimi zmianami odnośnie do formy zwyczajnej, natomiast w obrębie formy nadzwyczajnej nastąpiło kilka istotnych zmian ${ }^{4}$.

Obowiązujący Kodeks Prawa Kanonicznego, podobnie jak i poprzedni, rozróżnia formę zwyczajną i nadzwyczajną zawarcia małżeństwa. Niektóre z przepisów zostały przejęte z wcześniejszej regulacji, niektóre zostały nowelizowane, inne zaś stanowią novum na gruncie prawa kanonicznego.

W niniejszym studium uwaga zostanie poświęcona formie zwyczajnej zawarcia małżeństwa, jednak bez wątku uzupełnienia jurysdykcji, którą przewiduje kan. $144 \mathrm{KPK}^{5}$.

Zgoda małżeńska, o której czytamy w kan. 1057 KPK, w świetle obowiązującego ustawodawstwa musi bowiem zostać wyrażona „zgodnie z prawem”. Chodzi tu o przepisy prawa pozytywnego, które regulując obszar prawa małżeńskiego, chronią małżeństwo nie tylko

${ }^{2}$ Concilium Tridentinum, Decretum Tametsi, 11 november 1563 r., w: Denzinger H., Enchiridion symbolorum definitionum et declarationum de rebus fidei et morum, edizione bilingue a cura Peter Hünermann, Bolonia 1995, nn. 1797-1800.

${ }^{3}$ Sacra Congragatio Concilit, Decretum Ne temere de sponsalibus et matrimonio iussus et auctoritate SS. D.N. Pii Papae X a S. Congregatione Concilii editum, 2 augusti 1907, ASS 40 (1907), s. 525-530.

${ }^{4}$ Por. A. Tunia, Kształtowanie się kanonicznej formy zawarcia małżeństwa, Roczniki Nauk Prawnych 18 (2008), nr 1, s. 143-146.

${ }^{5}$ W myśl zasady Ecclesia supplet, Kościół uzupełnia jurysdykcję w wypadku błędu powszechnego, zarówno faktycznego, jak i prawnego, a także w wypadku uzasadnionej wątpliwości prawnej lub faktycznej. Mamy wówczas do czynienia z delegacją „a iure”, udzielaną w celu zabezpieczenia ważności aktu. 
jako dobro prywatne, ale także jako instytucję dobra publicznego. Interesujący nas zakres zwyczajnej formy zawarcia małżeństwa, kodeks z 1983 roku, reguluje dyspozycjami zawartymi w kan. 1108-1114 KPK, odnoszącymi się do świadka kwalifikowanego i świadków zwyczajnych zawarcia małżeństwa oraz delegacji upoważnienia do asystowania.

\section{Wymagania formy zwyczajnej zawarcia małżeństwa}

Mając na uwadze formę zawarcia małżeństwa w łacińskim Kościele katolickim, należy rozróżnić formę prawną oraz formę liturgiczną i formę sakramentu. Forma liturgiczna to obrzędy i ceremonie, które zawierają Obrzędy liturgiczne ${ }^{6}$, nie będące przedmiotem zainteresowania kanonistyki. Forma sakramentu obejmuje natomiast sam konsens nupturientów, wyrażający wzajemne ich oddanie się i wzajemne przyjęcie ${ }^{7}$.

Będąca przedmiotem niniejszej refleksji forma kanoniczna określa to, co jest wymagane do ważności zawarcia małżeństwa.

Zwyczajna forma kanoniczna polega na wyrażeniu przez strony zgody małżeńskiej wobec świadka kwalifikowanego bądź też jego delegata oraz wobec dwóch świadków zwykłych (kan. 1108) ${ }^{8}$. A zatem obecność świadków, a zwłaszcza kwalifikowanego, zwanego także świadkiem urzędowym, wpisuje się w formalizm, jaki obowiązuje przy dokonywaniu czynności prawnej, w tym przypadku do złożenia oświadczenia woli dotyczącej zawarcia małżeństwa. Akt ten musi

\footnotetext{
${ }^{6}$ Por. Konferencja Episkopatu Polski, Obrzędy sakramentu małzeństwa dostosowane do zwyczajów diecezji polskich, Katowice 1996.

${ }^{7}$ Por. P. MAJER, Znaczenie kanonicznej formy zawarcia małżeństwa, Annales Canonici 11 (2015), s. 136.

${ }^{8}$ „Kan. $1108 \$ 1$. Tylko te małżeństwa są ważne, które zostają zawarte wobec asystującego miejscowego ordynariusza albo proboszcza, albo wobec kapłana lub diakona delegowanego przez jednego z nich; a także wobec dwóch świadków, według zasad wyrażonych w następnych kanonach i z uwzględnieniem wyjątków, o których w kan. 144, 1112, $\$ 1,1116$ i 1127, $\$ \$ 2-3 . \$ 2$. Za asystującego przy zawieraniu małżeństwa uważa się tylko tego, kto jest obecny i pyta nowożeńców, czy wyrażają zgodę i przyjmuje ją w imieniu Kościoła”.
} 
być odpowiednio zamanifestowany, tak aby wola ta ujawniła się zewnętrznie w sposób dostateczny (por. np. art. 60 polskiego Kodeksu cywilnego).

W tym znaczeniu forma kanoniczna zawarcia małżeństwa nie może być traktowana w sposób szerszy, jednocześnie jednak nie może być zwykłą „formalnością”, bowiem jej znaczenie w sensie eklezjalnym jest znacznie głębsze. Ustanowiona przez władzę kościelną, jako wymóg ad validitatem matrimonii, domaga się publicznej formy zawarcia małżeństwa, która dokonując się wobec świadków (in facie Ecclesiae), chroni małżeństwo jako dobro publiczne oraz zachowuje prawo sprawowania przez Kościół jurysdykcji nad małżeństwem kanonicznym9 9

$\mathrm{Z}$ takiego ujęcia wypływają konkretne wymagania dotyczące świadków zawarcia małżeństwa, ale także różna ich rola i odmienne obowiązki.

\section{1. Świadek kwalifikowany z urzędu}

Zawarta w kan. $1008 \$ 2$ KPK dyspozycja przewiduje aktywną rolę świadka urzędowego. To on bowiem asystuje nupturientom przy zawieraniu małżeństwa, a zatem wymagana jest jego obecność w czasie i miejscu, w których się to dzieje, on także stawia im pytania o zgodę małżeńską, on też ją od nich przyjmuje w imieniu Kościoła.

Bardzo istotnym jest wyrażenie in nomine Ecclesiae, gdyż to właśnie sprawia, że świadek kwalifikowany czyni swoje powinności w imieniu Kościoła, dzięki nadanym przez niego kompetencjom, wypływającym ze sprawowanego urzędu. On to gwarantuje zachowanie formy kanonicznej małżeństwa, publiczny charakter jego zawarcia oraz sakramentalność, gdy spełnione zostają warunki ze strony nupturientów. W ten sposób zachowana zostaje prawna istota formy ad solemnitatem, ale także społeczny wymiar samego małżeństwa ${ }^{10}$.

\footnotetext{
${ }^{9}$ Por. P. Majer, Znaczenie kanonicznej formy zawarcia małżenstwa, dz. cyt., s. $137-138$

${ }^{10}$ Por. C. De Franciscis, La forma del matrimonio canonico, w: La centralità della persona nella giurisprudenza coram Serano, Studi Giuridici, t. 86, Città del Vaticano 2009, s. 203.
} 
Zgodnie z przepisami prawa, z chwilą objęcia urzędu ordynariusz miejsca lub proboszcz, posiadając władzę terytorialną, są kompetentni do asystowania przy zawieraniu małżeństw podlegających im wiernych, którzy na danym terenie zamieszkują na stałe lub tymczasowo, ale także tych, którzy jako „obcy”, czyli „niebędący podwładnymi” tylko na nim przebywają, pod warunkiem, że jedno z zawierających małżeństwo należy do Kościoła łacińskiego. Duchowni ci, aby mogli ważnie wypełniać swój urząd, nie mogą trwać w karach kościelnych, jak ekskomunika, interdykt czy suspensa, które to kary zostały im wymierzone bądź deklarowane wyrokiem sądu bądź dekretem przełożonego (kan. $1009 \mathrm{KPK})^{11}$. Jeśli kary te wiążą duchownego jako kary latae sententiae i nie zostały stwierdzone wyrokiem bądź dekretem,

\footnotetext{
${ }^{11}$ Kan. 1109 został zmodyfikowany w 2016 r., przez art. 7 motu proprio „De concordia inter Codices” i otrzymał następujące brzmienie: „Loci Ordinarius et parochus, nisi per sententiam vel per decretum fue - rint excommunicati vel interdicti vel suspensi ab officio aut tales de - clarati, vi officii, intra fines sui territorii, valide matrimoniis assistunt non tantum subditorum sed etiam, dummodo alterutra saltem pars sit adscripta Ecclesiae latinae, non subditorum". [Ordynariusz miejsca i proboszcz miejsca, o ile wyrokiem lub dekretem nie zostali ekskomunikowani, ukarani interdyktem lub suspendowani od urzędu albo takimi deklarowani, na mocy swego urzędu, w granicach własnego terytorium ważnie asystują przy małżeństwach nie tylko swoich podwładnych, lecz także niebędących podwładnymi, o ile przynajmniej jedna strona zapisana jest do Kościoła łacińskiego]. Franciscus, Litterae Apostolicae Motu Proprio Datae Quibus nonnullae normae Codicis Iuris Canonici immutantur, AAS 107 (2016), s. 603, art. 7. Tekst polski: R. Kamiński, H. Stawniak (red.), Chrzest i małżeństwo. Harmonizacja ustawodawstwa, Warszawa 2018, s. 202, art. 7. Nowelizacja kan. 1109 KPK sprawia, że nie ma wątpliwości, co do kompetencji ordynariusza miejsca oraz proboszcza do asystowania przy małżeństwie swoich podwładnych, także wówczas, gdy obaj należą do obrządków wschodnich. W przeszłości, z powodu umieszczenia kaluzuli dummodo eorum alteruter saltem sit ritus latini, przepis ten był różnie interpretowany. Na ten temat szerzej: H. STAWniak, Modyfikacje przepisów dotyczące formy zawarcia małżenstwa wprowadzone przez papieża Franciszka, w: R. Kamiński, H. Stawniak (red.), Chrzest i małżeństwo. Harmonizacja ustawodawstwa, Warszawa 2018, s. 89-94.
} 
nie unieważniają asystencji przy zawieraniu małżeństwa, ale czynią ją niegodziwą ${ }^{12}$.

Ogólne określenie posiadających władzę zwyczajną do asystencji przy zawieraniu małżeństw, ze względu na potencjalność wystąpienia różnych możliwości, domaga się precyzyjnego określenia, kogo w prawie kanonicznym rozumiemy pod pojęciami ordynariusza miejsca i proboszcza.

Do pierwszej kategorii osób zaliczymy: Biskupa Rzymskiego, który „Z racji swego urzędu, posiada (...) władzę najwyższą, pełną, bezpośrednią, powszechną władzę zwyczajną w Kościele, którą może wykonywać zawsze w sposób nieskrępowany (kan. $331 \mathrm{KPK}$ ); biskupa diecezjalnego oraz „innych, którzy - choćby tylko czasowo - są przełożonymi Kościoła partykularnego lub wspólnoty do niego przyrównanej zgodnie z kan. 368 (...)” (kan. 134 KPK). Są to więc: prałat i opat terytorialny, wikariusz i prefekt apostolski, administrator apostolski administratury apostolskiej erygowanej na stałe (kan. 368 KPK, kan. $381 \S 2$ KPK), administrator diecezji (kan. 427 $\$ 1 \mathrm{KPK}$ ); biskup koadiutor i biskup pomocniczy wyposażeni w specjalne uprawnienia (kan. $405 \$ 2 \mathrm{KPK}$, kan. $406 \$ 1 \mathrm{KPK}$ ); wikariusz generalny (kan. $134 \$ 1-2$ KPK, kan. $475 \$ 1$ KPK, kan. $479 \$ 1 \mathrm{KPK}$ ); wikariusz biskupi w granicach terytorium dla którego został ustanowiony (kan. 479 KPK); wikariusz biskupi w odniesieniu do wiernych obrządku dla których został ustanowiony, bądź też w odniesieniu dla grupy wiernych, dla których został ustanowiony (kan. $476 \mathrm{KPK}$ ); wikariusz biskupi ustanowiony dla innych określonych spraw w diecezji o ile w sprawach tych mieści się upoważnienie do asystowania przy zawieraniu małżeństw. Warto zaznaczyć, że kardynałowie, legaci papiescy (nawet w siedzibie poselstwa (kan. 366 n. 1 KPK), biskupi metropolici w diecezjach sufragalnych, jak również prymasi poza

\footnotetext{
${ }^{12}$ Por. T. PAwluk, Forma zawarcia małżeństwa $w$ świetle nowego Kodeksu Prawa Kanonicznego, Prawo Kanoniczne 27 (1984) nr 1-2, s. 44.
} 
swoją diecezją, nie posiadają zwyczajnej władzy do asystowania przy zawieraniu małżeństw ${ }^{13}$.

Pod pojęciem proboszcza rozumiemy przede wszystkim duchownego sprawującego ten urząd w sensie właściwym, którego kodeks definiuje jako własnego pasterza zleconej sobie parafii” (kan. 519 KPK). To on w granicach jej terytorium na mocy urzędu ważnie asystuje przy zawieraniu małżeństw i błogosławieniu ich, co kodeks formułuje wprost, jako jedną z jego funkcji specjalnych (por. kan. 530 n. 4 KPK).

Tam gdzie dla istniejącej przyczyny, jak np. język, obrządek, narodowość, utworzona została parafia personalna, jak przewiduje to kan. $518 \mathrm{KPK}$, a co za tym idzie także proboszcz personalny, posiada on władzę asystowania, wobec wiernych podlegających mu w granicach jego okręgu (por. kan. $1110 \mathrm{KPK}$ ).

Gdy jakaś wspólnota nie została jeszcze zorganizowana na tyle, by utworzyć z niej parafię na sposób stały, może zostać utworzona parafia tymczasowa, jak przewiduje to kan. $516 \$ 1 \mathrm{KPK}$. Na czele tak utworzonej parafii stoi proboszcz tymczasowy. Będąc własnym pasterzem powierzonej mu wspólnoty, ma on uprawnienia do asystowania i błogosławieństwa małżeństwom.

Jeśli biskup diecezjalny nie postanowi inaczej, takie same uprawienia jak proboszcz, a zatem także prawo do bycia świadkiem urzędowym przy zawieraniu małżeństw, posiada administrator parafii (por. kan. 540 KPK).

Gdyby w przypadku wakansu na urzędzie proboszcza, albo też gdyby proboszcz posiadał przeszkodę w pełnieniu urzędu, a nie zostałby jeszcze ustanowiony administrator (por. kan. $541 \$ 1 \mathrm{KPK}$ ) lub też gdyby proboszcz był nieobecny (por. kan. $533 \$ 3 \mathrm{KPK}$, kan. 549 KPK), uprawnienia, o których powyżej, posiada wikariusz parafialny, bądź też kapłan, który zarządza parafią.

Prawo przewiduje także sytuację, w której możliwe jest powierzenie poszczególnym kapłanom, należącym do zespołu, pasterskiej

\footnotetext{
${ }^{13}$ Por. J. RAPACz, Zwyczajna forma zawarcia małżeństwa według Kodeksu Jana Pawła II, Prawo Kanoniczne 41 (1998), nr 1-2, s. 240.
} 
posługi w jednej lub kilku parafiach. W takiej sytuacji władza asystowania przy zawieraniu małżeństwa przysługuje wszystkim, ale należy z niej korzystać pod kierownictwem moderatora (por. kan. $543 \$ 1 \mathrm{KPK})$.

Osobną, specjalną kategorią duchownych są kapelani wojskowi. Na mocy mianowania w ramach ordynariatu cieszą się oni prawami i obowiązkami proboszczów, chyba że natura rzeczy lub statuty partykularne wskazują co innego ${ }^{14}$.

Kapelan posiada zatem uprawnienia do asystowania małżeństwom wiernych, którzy mu podlegają w granicach jego okręgów ${ }^{15}$. W przypadku, gdy żadne z nupturientów nie podlega jurysdykcji kapelana, może on ważnie asystować przy zawieraniu małżeństwa wyłącznie

${ }^{14}$ Jan PAweŁ II, Konstytucja apostolska Spirituali militium curae z dnia 21 kwietnia 1986 r., w: Enchiridion Vaticanum. Documenti ufficiali della Santa Sede, t. 10, Bolonia 1990, n. 362.

${ }^{15}$ Konstytucja Spirituali militium curae zalicza tu następujące kategorie wiernych: „1. Wierni będący żołnierzami oraz ci, którzy pracują dla sił zbrojnych, jeśli ich związek z armią jest uznany przez prawo cywilne; 2 . Członkowie ich rodzin, mianowicie współmałżonkowie i dzieci - także jeśli są samodzielne - zamieszkujący w tym samym domu, a także krewni i służba, zamieszkujący pod tym samym dachem; 3 . Ci, którzy uczęszczają do szkół wojskowych, przebywają w wojskowych szpitalach, domach starców lub innych podobnych miejscach, również personel tych instytucji; 4. Wszyscy wierni obojga płci, niezależnie od tego, czy należą, czy nie należą do zgromadzenia zakonnego, którzy na polecenie lub za zgoda ‘ ordynariusza wojskowego pełnia ، jakieś stałe funkcje”. JAN PAWEŁ II, Konstytucja Apostolska Spirituali militium curae, 25 kwietnia 1986, art. X. Listę tę uszczegółowia Statut Ordynariatu Wojskowego czyli Polowego w Polsce: „Do Ordynariatu Polowego należą katolicy:

a) żołnierze zawodowi, ich współmałżonkowie, dzieci, także pełnoletnie, o ile mieszkają w domu rodziców oraz rodzice i krewni zamieszkujący razem z nimi; b) żołnierze w czynnej służbie wojskowej (niezawodowi), w czasie pełnienia tej służby; c) pracownicy cywilni, zatrudnieni na stałe w jednostkach (instytucjach) wojskowych oraz w domach prywatnych osób pełniących zawodową służbę wojskową; d) uczniowie szkół wojskowych; e) zatrudnieni lub przebywający w szpitalach wojskowych, w domach starców i w podobnych instytucjach wojskowych; f) członkowie instytutów zakonnych i wierni świeccy zatrudnieni na stałe przez Ordynariusza Polowego lub za jego zgodą. Por. Statut Ordynariatu Wojskowego czyli Polowego w Polsce, https://ordynariat.wp.mil.pl/pl/articlesdokumenty-p/1991-01-21i-statut-ordynariatu-wojskowego-czyli-polowego-w-polsce/ (dostęp 29.07.2019), pkt. I, n. 3. 
po otrzymaniu delegacji od ordynariusza miejsca lub proboszcza terytorialnego, czyli proboszcza tej parafii diecezjalnej, na terenie której jest zawierane małżeństwo (kan. $1108 \mathrm{KPK})^{16}$.

${ }^{16}$ Dnia 17 czerwca 2009 r., Ordynariusz Polowy bp Tadeusz Płoski skierował pismo do Przewodniczącego Rady Prawnej Konferencji Episkopatu Polski, w którym informował, że „od chwili przywrócenia Ordynariatu Polowego kapelani wojskowi proboszczowie w przypadkach, gdy żadne $\mathrm{z}$ nupturientów nie przynależało do Ordynariatu Polowego, asystowali przy zawieraniu tych małżeństw na podstawie zezwolenia oraz delegacji uzyskanej od własnego ordynariusza lub własnego proboszcza jednej ze stron. Praktyka ta przy zawieraniu tego typu małżeństw była w duszpasterstwie wojskowym powszechną, a podejmowane działania przez księży kapelanów były w dobrej wierze". List Biskupa Polowego do Przewodniczącego Rady Prawnej Konferencji Episkopatu Polski z dnia 17 czerwca 2009 roku, l.dz. 563/CP KEP/2009, w: AKBOP, teczka Sanacja.

Sprawę uprawnienia do asystowania przy zawieraniu małżeństw w Ordynariacie Polowym ostatecznie uporządkował dopiero dekret biskupa polowego z 6 czerwca 2011 roku. Biskup Józef Guzdek nakazał w nim w szczególności przestrzeganie kanonu 1110 KPK. W praktyce oznacza to, że jeśli żaden z nupturientów nie podlega jurysdykcji kapelana danej parafii, może on ważnie asystować przy zawieraniu małżeństwa wyłącznie po otrzymaniu delegacji od ordynariusza miejsca lub proboszcza terytorialnego, czyli proboszcza tej parafii diecezjalnej, na terenie której jest zawierane małżeństwo (kan. $1108 \mathrm{KPK}$ ). Taka delegacja musi być przekazana w sposób wyraźny, a jeśli jest delegacją ogólną ma być obowiązkowo udzielona na piśmie (kan. $1111 \$ 2 \mathrm{KPK}$ ). W przypadku braku właściwej jurysdykcji nie jest wystarczająca licencja uzyskana od proboszcza miejsca zamieszkania któregoś z nupturientów, gdyż żaden proboszcz terytorialny nie może nikomu ważnie udzielić delegacji poza swoim terytorium (kan. $1111 \$ 1 \mathrm{KPK}$ ). Por. Dekret Biskupa Polowego Józefa Guzdka w sprawie jurysdykcji księży kapelanów do ważnego asystowania przy zawieraniu związków małżeńskich z 6 czerwca 2011 roku, 1. dz. 669/CD/2011, w: AKBOP, teczka CD.

Postanowienia dekretu zostały szerzej omówione w Pro memoria, opublikowanym z polecenia Biskupa Polowego dnia 18 września 2015 roku (Pro memoria w sprawie ważnego asystowania przy zawieraniu małżństw w Ordynariacie Polowym Instrukcja do dekretu ogólnego Biskupa Polowego z dnia 6 czerwca 2011, 18 września 2015, l. dz. 1417/CD/2015, w: AKBOP, teczka CD). W dokumencie tym przypomniano zasady przynależności do Ordynariatu Polowego zawarte w Konstytucji apostolskiej Spirituali militum curae oraz w Statucie Ordynariatu Polowego. Została również przedstawiona argumentacja za przynależnością do parafii wojskowej zarówno z tytułu służby w danej jednostce wojskowej, jak i zamieszkania na terenie 
Ostatnią grupą duchownych, którzy posiadają władzę równą proboszczom, są kapelani emigrantów w stosunku do wiernych, którzy podlegają w granicach ich okręgów. Są oni traktowaniu jako kapelani lub misjonarze, którym powierzono parafię personalną ${ }^{17}$.

Dla uzupełnienia całości zagadnienia warto dodać, że rektor seminarium również pełni funkcję proboszcza wobec przebywających w seminarium, jednak $\mathrm{z}$ wyjątkiem spraw dotyczących małżeństwa ${ }^{18}$.

\section{2. Świadek kwalifikowany delegowany}

Oprócz uprawnienia do asystowania przy zawieraniu małżeństw, które przysługuje ordynariuszowi miejsca i proboszczowi z urzędu, mogą oni delegować upoważnienie do asystencji innym kapłanom, diakonom, a także w określonych warunkach także osobom świeckim.

\subsubsection{Delegacja kapłana}

Delegacja, o której mowa w kan. 1008 i kan. 1111 KPK, może zostać udzielona przez ordynariusza i proboszcza, tak długo jak ważnie

określonego garnizonu. Następnie pro memoria proponuje rozwiązanie, według którego w przypadku wiernych wojskowych nie podlegających jurysdykcji danego proboszcza, może on uzyskać delegację do ważnego pobłogosławienia danego związku od Biskupa Polowego, jako ordynariusza wszystkich wojskowych. Na zakończenie zostało przypomniane, że delegacja ogólna powinna być udzielona na piśmie i że z natury swojej jest udzielana osobie, a nie dla urzędu. Szerzej na ten temat: J. Dohnalik, Ogólna sanatio in radice udzielona przez Stolice Apostolska (kan. $1165 \$ 1$ 1). Przykład uważnienia małżeństw zawartych bez zachowania formy kanonicznej w Ordynariacie Polowym, Ius Matrimoniale 29 (2018) nr 3, s. 43-62. Już znacznie wcześniej na temat niemożliwości delegowania przez proboszcza parafii wojskowej pisał wybitny kanonista Remigiusz Sobański. Por. R. SoBAŃski, Czy proboszcz parafii wojskowej może delegować upoważnienie do asystowania przy zawieraniu małżeństwa?, Prawo Kanoniczne 44 (2001) n. 1-2, s. 20.

${ }^{17}$ Kongregacja Biskupów, Instrukcja Nemo est z dnia 22 sierpnia 1969, w: Enchiridion Vaticanum. Documenti ufficiali della Santa Sede, t. 3., Bolonia 1985, n. 1576-1579.

${ }^{18}$ Por. J. RAPACZ, Zwyczajna forma zawarcia małżeństwa wedtug Kodeksu Jana Pawta II, dz. cyt., s. 242, przyp. 4. 
sprawują oni swój urząd ${ }^{19}$. Może zostać ona udzielona tylko w granicach ich terytorium. Jest to rodzaj delegacji ab homine, czyli udzielana przez tych, którzy posiadają władzę zwyczajną związaną z urzędem ${ }^{20}$.

Delegacja może zostać udzielona jako upoważnienie ogólne do asystowania przy zawieraniu małżeństw (delegatio generalis). W takim przypadku winna być ona zawsze udzielona na piśmie. Obejmuje ona wówczas wszystkie małżeństwa, jakie mogą zdarzyć się na terenie parafii (ad universitatem casum). W praktyce, w dekrecie kierującym danego kapłana do pracy w parafii w funkcji wikariusza biskup diecezjalny zawiera delegację do asystowania przy małżeństwach zawieranych na terenie tej parafii.

Forma ogólnego upoważnienia jest nowością, wprowadzoną przez Kodeks z 1983 roku. We wcześniejszym ustawodawstwie takiej delegacji można było udzielić wikariuszowi parafialnemu w granicach parafii, w której pełnił swoją posługę. W odniesieniu do innych kapłanów

${ }^{19}$ Biskup diecezjalny traci swój urząd w diecezji na skutek zrzeczenia się przyjętego przez papieża, przeniesienia do innej diecezji, (w której od chwili otrzymania wiadomości o przeniesieniu, jest administratorem) oraz pozbawienia go diecezji (por. kan. 416 KPK). Z chwilą zawakowania diecezji swoją władzę zwyczajną tracą również wikariusz generalny i wikariusz biskupi (kan. $418 \$ 2$ n. 1 KPK), o ile urzędów tych nie pełnił biskup pomocniczy (kan. $409 \$ 2$ ). On też do chwili mianowania administratora diecezji, sprawuje jej zarząd (w przypadku kilku - najstarszy promocją). W diecezji bez biskupa pomocniczego, w przypadku wakansu zarządza nią kolegium konsultorów, o ile Stolica Apostolska nie postanowi inaczej (kan. 419 KPK).

Proboszcz natomiast traci swój urząd na mocy dekretu biskupa diecezjalnego usuwającego go z urzędu (kan. 1740-1747 KPK) bądź też przenoszącego go na inny urząd (kan. 1748-1752 KPK), a także na skutek zrzeczenia się, przyjętego przez biskupa. Gdyby urząd proboszcza został nadany na czas określony, proboszcz traci go, po upływie tego czasu (kan. $538 \$ 1 \mathrm{KPK}$ ).

Parafia powierzona zespołowi kapłanów, nie wakuje, jeśli jeden z nich traci swój urząd. W takim przypadku, władzę proboszczowską pełnią pozostali kapłani. Gdyby zaś zabrakło moderatora, jego funkcję do czasu mianowania nowego, pełni w zespole kapłan najstarszy nominacją (kan. 544 KPK). Por. T. PAwLUK, Forma zawarcia małżenstwa w świetle nowego Kodeksu Prawa Kanonicznego, dz. cyt., s. 45.

${ }^{20}$ Por. J. RAPACZ, Zwyczajna forma zawarcia matżeństwa według Kodeksu Jana Pawła II, dz. cyt., s. 243. 
można było udzielić tylko delegacji do błogosławienia poszczególnych małżeństw ${ }^{21}$.

Delegacja może mieć też postać upoważnienia specjalnego (delegatio specialis), co oznacza, że została udzielona do asystowania i błogosławienia przy zawarciu określonego małżeństwa (ad actum). Ten rodzaj delegacji może zostać udzielony ustnie (kan. 137 KPK).

Tak udzielona delegacja musi zostać udzielona do małżeństwa, które zostało określone przez podanie imion i nazwisk nupturientów, ewentualnie pozycji w księdze zapowiedzi, daty, godziny i miejsca ślubu ${ }^{22}$.

Delegacji do asystowania zawarciu małżeństwa można udzielić $\mathrm{w}$ formie przewidzianej w kan. $140 \$ 1 \mathrm{KPK}$. Jest to wyznaczenie świadka kwalifikowanego przez delegowanie solidarne (in solido). W myśl tej normy gdy do asystowania zostałoby delegowanych solidarnie kilku duchownych, ten, kto pierwszy zacząłby załatwiać sprawę, wykluczyłby od tego samego działania innych.

Zgodnie z $\$ 2$ kan. 1111 KPK, aby delegacja była ważna, wymaga się, by została przekazana określonym osobom (determinatis personis dari debet) w sposób wyraźny (expresse dari debet). Kapłan lub diakon zostaje określony, jeśli delegacja zawiera jego imię i nazwisko, ewentualnie urząd, a zatem dane, które jednoznacznie będą go identyfikować 23 .

\footnotetext{
${ }^{21}$ Por. K. Dullak, Podstawy prawne zwyczajnej formy zawarcia małżństwa w Konkordacie z 1993 r., Studia z Prawa Wyznaniowego 8 (2005), s. 197.

${ }^{22}$ Nieważna będzie delegacja, która została udzielona np. do asystowania małżeństwom, które będą zawierane w danym miejscu w ciągu danego miesiąca. Ważność w takim przypadku miałaby delegacja udzielona na piśmie na wzór delegacji ogólnej przez ordynariusza miejsca lub proboszcza. Por. T. PAWLuk, Forma zawarcia małżeństwa w świetle nowego Kodeksu Prawa Kanonicznego, dz. cyt., s. 46-47.

${ }^{23}$ Nieważnie udzielona będzie delegacja np. jednemu z kapłanów, który przyjdzie zastąpić proboszcza, albo też kapłanowi, którego wybiorą sobie nowożeńcy, albo też kapłanowi którego przełożony zakonny wyznaczy w tym dniu do odprawiania Mszy św. w danym kościele. Por. Pontificia Commissio ab Codicis Canones AUthentiCe INTERPRETANdos, Circa assistentiam matrimoniis (can. 1096, \$1), 20 maja 1923, AAS 16 (1924), s. 115.
} 
Wyraźny sposób udzielenia delegacji zakłada wykluczenie domniemania. Jak zauważa Tadeusz Pawluk, nawet obecność proboszcza, który nie sprzeciwia się, widząc że duchowny nieupoważniony przygotowuje się do celebracji, nie oznacza udzielenia delegacji. Delegacja musi być wyrażona zewnętrznie słowami lub na piśmie. Duchowny, który oznajmia proboszczowi, że do asystowania został delegowany przez ordynariusza miejsca, powinien to udowodnić (kan. 131 § $3 \mathrm{KPK})^{24}$.

Do ważności delegacji jurysprudencja wymaga, aby delegacja została przez delegowanego zaakceptowana ${ }^{25}$.

Godnym podkreślenia jest także, że duchowny, który otrzymał delegację do asystowania przy ślubie, otrzymuje także władzę dyspensowania od przeszkód małżeńskich, w takim samym zakresie i pod takimi samymi warunkami jak proboszcz (kan. $1079 \$ 2$ KPK, kan. $1080 \$ 1 \mathrm{KPK})$. Delegowany także, o ile delegujący nie zlecił tego

Z kwestią określenia duchownego wiąże się także prawidłowe wpisanie jego imienia i nazwiska oraz zajmowanego stanowiska, które uprawnia go do asystowania przy zawieraniu danego małżeństwa, jeśli jest to tzw. małżeństwo konkordatowe. Na właściwe sporządzenie „Zaświadczenia” przez duchownego i dostarczanego do USC, zwraca uwagę instrukcja Konferencji Episkopatu Polski, przewidując ograniczone możliwości: „W odpowiednim miejscu „Zaświadczenie” podpisuje także duchowny, zobowiązany do przesłania go urzędowi stanu cywilnego, a więc: proboszcz, administrator parafii, albo wikariusz w zastępstwie proboszcza. Obok imienia i nazwiska ma on obowiązek wskazać stanowisko, z racji którego ma prawo podpisać „Zaświadczenie”. Zatem, po jego imieniu i nazwisku należy dodać jedno z określeń zajmowanego stanowiska, według niżej podanych możliwości: ordynariusz miejsca/proboszcz/administrator parafii/wikariusz w zastępstwie proboszcza/ duchowny w zastępstwie proboszcza". Tak więc każdy inny duchowny, nie pełniący wskazanych wprost urzędów, niezależnie od posiadanych godności czy pełnionych innych urzędów, występuje jako duchowny delegowany „w zastępstwie proboszcza”. KonferencJa EPiskopatu Polski, Instrukcja dla duszpasterzy, dotyczaca małżeństwa konkordatowego, 12 listopada 1998, https://archpoznan.pl/upload/pdf/synod/ t207.pdf (dostęp 31.07.2019), pkt. III, $18 \mathrm{~d}$.

${ }^{24}$ Por. T. PAwluk, Forma zawarcia matżeństwa $w$ świetle nowego Kodeksu Prawa Kanonicznego, dz. cyt., s. 46.

${ }^{25}$ Por. R. Navarro VAlls, La reforma della celebrazione del matrimonio, w: Codice di diritto canonico, t. 2, Roma 1987, s. 799. 
innemu duchownemu, jest zobowiązany stwierdzić zgodnie z przepisami prawa stan wolny nupturientów ${ }^{26}$. Gdyby tego nie uczynił, działałby niegodziwie (por. kan. 114 KPK).

\subsubsection{Delegacja diakona}

Przewidziana w kan. 1008 KPK możliwość zawarcia małżeństwa wobec delegowanego diakona jest novum, które pojawia się w Kodeksie Prawa Kanonicznego z 1983 roku. We wcześniejszej kodyfikacji przewidziana była tylko delegacja ogólna dla wikariusza współpracownika (pomocnika). Obecnie nie stosuje się podziału na wikariuszy współpracowników (pomocników) i wikariuszy zastępców. W świetle obowiązującego ustawodawstwa delegację ogólną czy też specjalną może otrzymać także każdy diakon.

Dopuszczenie diakona, tak stałego, jak i kandydata do prezbiteratu, do wykonywanie, tego uprawnienia jest realizacją soborowej doktryny, zawartej w konstytucji Lumen gentium, która jako jedno z zadań diakona wyznacza „asystowanie i błogosławienie w imieniu Kościoła związkom małżeńskim”27.

Posoborowe prawodawstwo przewiduje dla diakona możliwość asystowania przy zawieraniu małżeństw ${ }^{28}$. Także Kodeks z 1983, przyznaje mu stosowne miejsce w części poświęconej formie zawarcia małżeństwa kanonicznego (kan. $1008 \$ 1$ KPK, kan. $1111 \$ 1$ KPK, kan. $1112 \$ 1 \mathrm{KPK}$, kan. $1116 \$ 2 \mathrm{KPK})$. Na gruncie polskim jeszcze przed wejściem w życie Kodeksu z 1983 roku asystowanie diakona mimo że było już możliwe, nie było zalecane ${ }^{29}$.

\footnotetext{
${ }^{26}$ Por. T. Pawluk, Forma zawarcia małżeństwa $w$ świetle nowego Kodeksu Prawa Kanonicznego, dz. cyt., s. 48.

${ }^{27}$ Concilum Vaticanum II, Constitutio dogmatica de Ecclesia Lumen gentium, 21 listopada 1964, AAS 57 (1965), n. 29. Tekst polski: Soвór WATyкAŃski II, Konstytucja dogmatyczna o Kościele Lumen gentium, 21 listopada 1964, w: TenżE, Konstytucje - Dekrety - Deklaracje, Poznań 2012, n. 29 (dalej: LG).

${ }^{28}$ Paulus VI, Motu proprio, Sacrum diaconatus ordinem z dnia 18 czerwca 1967 r., AAS 59 (1967), art. 22, n. 4.

${ }^{29}$ Konferencja Episkopatu Polski dnia 11 marca 1973 roku zaleciła, aby „ze względu na warunki duszpasterstwa w Polsce, (...) nie delegować diakonów do asystowania
} 
Istotnej zmiany dotyczącej asystowania diakona przy zawieraniu małżeństw dokonał papież Franciszek w motu proprio „De concordia inter Codices", mającym na celu harmonizację ustawodawstwa łacińskiego i wschodniego. Mimo że tematem niniejszego opracowania nie jest szczegółowa analiza formy zawierania małżeństw mieszanych, należy wskazać w tym miejscu na zmianę dotyczącą wykluczenia diakona $\mathrm{z}$ delegacji do asystowania małżeństwu zawieranego przez katolika łacinnika i katolika obrządku wschodniego albo też katolika łacinnika i prawosławnego lub też dwóch katolików wschodnich. Tego typu zmianę ustawodawca wprowadza, dodając do kan. 1008 KPK paragraf trzeci, który należy interpretować łącznie $\mathrm{z}$ również znowelizowanymi kan. $1111 \S 1 \mathrm{KPK}$ i kan. $1127 \$ 1 \mathrm{KPK}^{30}$.

przy zawieraniu małżeństw”. Konferencja Episkopatu Polski, Obrzędy sakramentu małżeństwa dostosowane do zwyczajów diecezji polskich, Katowice 1974, s. 30, nr 59, przyp. 15. T. Pawluk twierdził, że zalecenie to należy rozumieć, jako zwykłą dyrektywę, a nie ustawę uniezdalniającą. Por. T. PAwluk, Forma zawarcia małżeństwa w świetle nowego Kodeksu Prawa Kanonicznego, dz. cyt., przyp. 16. „Wszelkie wątpliwości jednoznacznie rozwiewa najnowsze wydanie odnowionych Obrzędów sakramentu małżeństwa dostosowanych do zwyczajów diecezji polskich (wydanie trzecie według drugiego wydania wzorcowego, Katowice 2002). Rytuał małżeństwa nie zawiera już żadnej wzmianki o dawnej dyrektywie biskupów polskich, ale wyraźnie przypomina, jakie jest aktualnie obowiązujące (również i u nas) prawo: „Także diakon, który otrzymał upoważnienie od proboszcza lub od miejscowego ordynariusza, może przewodniczyć sprawowaniu sakramentu małżeństwa, nie wykluczając błogosławieństwa małżonków” (s. 17, nr 24). Podobnie w innym miejscu „Obrzędów” mówi się jasno: „Obrzęd tutaj podany sprawuje kapłan lub diakon, który otrzymał od miejscowego ordynariusza lub od proboszcza delegację do asystowania i błogosławienia w imieniu Kościoła zawieranym małżeństwom” (s. 54, nr 122; zob. także nr 123)". P. MAJER, Uwagi na temat asystowania diakona przy zawieraniu matżeństwa, http://www.kefas-piotr.wiara.pl/index.php?idz=1\&kat=06\&txt=15. txt\&nazw=Uwagi\%20na\%20temat\%20asystowania\%20diakona\%20przy\%20zawieraniu\%20ma\%B3\%BFe\%F1stwa (dostęp 31.07.2019).

${ }^{30}$ „Art. 6. Canon 1108 CIC posthac tertiam paragraphum habebit ut sequitur: $₫ 3$. Solus sacerdos valide assistit matrimonio inter partes orientales vel inter partem latinam et partem orientalem sive catholicam sive non ca - tholicam. [Art. 6. Kan. 1108 KPK otrzymuje od tego momentu paragraf trzeci z następującym brzmieniem: $\S 3$. Tylko kapłan ważnie asystuje przy zawieraniu małżeństwa między dwiema stronami wschodnimi lub między stroną łacińską i stroną wschodnią czy to katolicką, 
Dodany do kan. 1108 nowy paragraf w istocie wyklucza możliwość delegowania diakona łacinnika oraz osoby świeckiej do asystowania przy małżeństwie zawieranym między dwiema osobami należącymi do obrządku wschodniego lub między stroną łacińską i stroną wschodnią, czy to katolicką, czy to niekatolicką. Jak zauważa Henryk Stawniak, wiąże się to z rolą kapłana, jaką przypisuje teologia i sam obrzęd małżeństwa w Kościołach wschodnich, gdzie małżeństwo jest związane ściśle z błogosławieństwem kapłańskim. On jest szafarzem małżeństwa, a nie tylko świadkiem przyjmującym zgodę małżeńską nupturientów. We wspólnotach tych w znaku sakramentalnym małżeństwa współdziałają zarówno strony, jak i kapłan. Sprawując ritus sacer, współdziała on wraz z małżonkami, którzy w zwykłych warunkach są szafarzami sakramentu wraz z kapłanem. Interwencja kapłana jest prawdziwie sakramentalna, stąd też diakon łacinnik czy też osoba świecka nie mogą zostać delegowani do błogosławienia

czy to niekatolicką]. Art. 8. Prima paragraphus can. 1111 CIC integre sequenti textu substituitur: $\$ 1$. Loci Ordinarius et parochus, quamdiu valide officio funguntur, possunt facultatem intra fines sui territorii matrimoniis assistendi, etiam generalem, sacerdotibus et diaconis delegare, firmo tamen eo quod praes - cribit can. $1108 \$ 3$. [Art. 8. Pierwszy paragraf kan. 1111 KPK zostaje zastąpiony następującym tekstem: $\$ 1$. Ordynariusz miejsca i proboszcz miejsca, dopóki ważnie sprawują swój urząd, mogą delegować kapłanom i diakonom uprawnienie - również ogólne - do asystowania przy zawieraniu małżeństw $\mathrm{w}$ granicach swego terytorium, $\mathrm{z}$ zachowaniem przepisu kan. $1108 \$ 3$ ]. Art. 11. Prima paragraphus can. 1127 CIC integre sequenti textu substituitur: $\$ 1$. Ad formam quod attinet in matrimonio mixto adhibendam, serventur praescripta can. 1108; si tamen pars catholica matrimonium contrahit cum parte non catholica ritus orientalis, forma canonica celebrationis servanda est ad liceitatem tantum; ad validitatem autem requiritur interventus sacerdotis, servatis aliis de iure servandis. [Art. 11. Pierwszy paragraf kan. 1127 KPK zostaje zastąpiony następującym tekstem: $₫ 1$. Co do formy małżeństwa mieszanego, należy zachować przepisy kan. 1108; jeżeli jednak małżeństwo zawiera strona katolicka ze stroną niekatolicką obrządku wschodniego, kanoniczna forma zawarcia wymagana jest tylko do godziwości; do ważności zaś konieczny jest udział kapłana, z zachowaniem innych wymogów prawa]". Franciscus, Litterae Apostolicae Motu Proprio Datae Quibus nonnullae normae Codicis Iuris Canonici immutantur, dz. cyt, art. 6-11. Tekst polski: R. Kamiński, H. Stawniak (red.), Chrzest i małżeństwo. Harmonizacja ustawodawstwa, dz. cyt., s. 202-203, art. 6-11. 
małżeństw w porządku prawnym Kościołów wschodnich ${ }^{31}$. W żadnym z Kościołów wschodnich małżeństwa nie były nigdy błogosławione przez diakonów. Do tego zadania byli i są uprawnieni jedynie biskupi i prezbiterzy ${ }^{32}$. Były też od czasów wczesnochrześcijańskich zawierane w czasie Eucharystii sprawowanej przez kapłanów ${ }^{33}$.

\subsubsection{Delegacja wiernego świeckiego}

Oprócz omówionych wyżej możliwości delegowania uprawnienia do asystowania przy zawieraniu małżeństw, Kodeks z 1983 roku przewiduje jeszcze jedną możliwość, która jest wyjątkiem od reguł zawartych w kan. $1108 \$ 1$ i $\$ 3 \mathrm{KPK}$. Chodzi tu o przewidzianą w kan. 1112 KPK możliwość delegowania osoby świeckiej (laicos), która staje się na mocy delegacji urzędowym świadkiem, asystującym w imieniu Kościoła nupturientom, odbierając od nich zgodę małżeńską.

Chociaż sam przepis jest nowy, to w pewnym sensie sankcjonuje on praktykę, która w niektórych regionach miała miejsce jeszcze przed pojawieniem się referowanej normy, kiedy to biskupi po uzyskaniu pozytywnej opinii Konferencji Biskupów starali się o zezwolenie Stolicy Apostolskiej na powierzanie osobie świeckiej funkcji świadka kwalifikowanego w ściślejszym znaczeniu ${ }^{34}$.

\footnotetext{
${ }^{31}$ Por. H. Stawniak, Modyfikacje przepisów dotyczące formy zawarcia malżeństwa wprowadzone przez papieża Franciszka, dz. cyt., s. 107.

${ }^{32}$ Por. J. Prader, Matrimonio in Oriente e in Occidente, Roma 2003, s. 226; KKK, art. 1623.

${ }^{33}$ Por. G. KadzIOCH, Il ministro del sacramento del matrimonio nella tradizione e nel diritto canonico latino e oriente, Roma 1997, s. 222.

${ }^{34}$ Warto zauważyć, że już w czasie dyskusji na Soborze Trydenckim, przy temacie małżeństwa tajnych była podnoszona także kwestia możliwości zawierania małżeństw przed osobami świeckimi. Podobnie było to przedmiotem prac przygotowawczych do Soboru Watykańskiego II, przy okazji omawiania kwestii formy kanonicznej małżeństwa, szczególnie w warunkach misyjnych. Por. L. SABbARESE, I laici "testi qualificati” per assistere al matrimonio. Aspetti storici, interpretativi e aplicativi, w: J. Pudumai Doss, M. Graulich (red.), Iustitiam et iudicium facere. Scritti in onore del Prof. Don Sabino Ardito SDB, Roma 2011, s. 50-56.

Jak zauważa T. Pawluk, o taką formę biskupi zwracali się do Stolicy Apostolskiej także w latach sześćdziesiątych ubiegłego stulecia, postulując, aby w razie
} 
Przepisy nie precyzują wyraźnie pozycji prawnej świeckiego świadka kwalifikowanego, chociaż prawodawca stawia konkretne warunki tak od strony władzy kościelnej, jak i od strony samego delegowanego, nie rozróżniając jednak, czy chodzi o kobietę czy też mężczyznę ${ }^{35}$.

Wymagania stawiane władzy kościelnej ustawodawca zawarł w $₫ 1$ kan. 1112 KPK.

Po pierwsze, zastosowanie przepisu jest możliwe jedynie tam, „gdzie nie ma kapłanów lub diakonów” (kan. $1112 \$ 1$ ). Określenie to należy rozumieć jako sytuację szczególną, która może mieć miejsce w niektórych regionach, gdzie zachodzi rzeczywisty i stały brak duchownych $^{36}$. Dlatego też, jak przekonuje T. Pawluk, „(...) nieuzasadniona

nieobecności kapłana lub diakona, mogła ona zastąpić formę nadzwyczajną zawarcia małżeństwa. W „Instrukcji” z dnia 7 grudnia 1971 r., Kongregacja Sakramentów, pouczyła hierarchów, że istniejącej formy nadzwyczajnej nie można w ten sposób zastąpić, jako słusznej w szczególnych sytuacjach nupturientów, ale jednocześnie zezwoliła, aby biskupi mogli powoływać świeckich do asystowania małżeństwom zawieranym $\mathrm{w}$ formie nadzwyczajnej, pozostawiając możliwość zawierania małżeństwa we właściwej dla tej formy obecności tylko dwóch świadków zwykłych. W takim jednak przypadku osoba świecka nie mogła być uważana, za świadka kwalifikowanego. Tekst polski instrukcji w: E. SzTafrowski (red.), Posoborowe prawodawstwo kościelne, t. 6, z. 2, Warszawa 1975, s. 361-367; Por. T. PAwLuK, Forma zawarcia małżeństwa w świetle nowego Kodeksu Prawa Kanonicznego, dz. cyt., s. 48; Por. Communicationes 10 (1978), s. 92 . W dużej mierze kwestię asystowania świeckich uregulowała instrukcja Sacramentalem indolem, adresowana do Przewodniczącego Episkopatu Brazylii, gdzie praktyka delegowania świeckich aż do ok. roku 1990 zdarzała się najczęściej. Por. Sancta Congregatione pro Culto Divino, Instructio Sacramentalem indolem, 15 maii 1974, w: Enchiridion Vaticanum. Documenti ufficiali della Santa Sede, t. 5, Bologna 1986, n. 479-488; L. SABBARESE, I laici ,testi qualificati” per assistere al matrimonio, dz. cyt., s. 60.

${ }^{35} \mathrm{~W}$ niektórych kręgach kulturowych (np. Indie, Gwatemala) delegowanie kobiet spotyka się jednak z opozycją, mimo że prawodawca nie warunkuje udzielania tego uprawnienia ze względu na płeć. Por. L. SABBARESE, I laici „testi qualificati” per assistere al matrimonio, dz. cyt., s. 61, 65.

${ }^{36}$ L. Sabbarese, w artykule z roku 2011, wymienia Konferencje Biskupów, które w swoich przepisach partykularnych, przewidują możliwość delegowania osób świeckich, zgodnie z normą kan. 1112 KPK. Na stan ówczesny były to episkopaty następujących krajów: Boliwia, Kanada, Chile, Ekwador, Gwatemala, Indie, Meksyk, 
byłaby prośba biskupa diecezjalnego, o zezwolenie na korzystanie z tego przepisu dla samej wygody proboszczów, choćby obarczonych licznymi obowiązkami duszpasterskimi" ${ }^{37}$.

Niemożność wykonywania swych funkcji przez duchownych, oprócz skutku niewystarczającej ich liczby na danym terenie, może wynikać także z prześladowań religijnych czy politycznych ${ }^{38}$.

Po drugie, inaczej niż ma to miejsce w przypadku kapłana czy diakona, których może delegować ordynariusz miejsca lub proboszcz, delegacja osoby świeckiej jest wyłączną kompetencją biskupa diecezjalnego. On też, wyłączając jakąkolwiek delegację, sam osobiście ma wybrać katolika, który winien spełniać tę funkcję ${ }^{39}$.

Nowa Zelandia, kraje Pacyfiku, Peru, Stany Zjednoczone, Wenezuela. Por. L. SABBARESE, I laici "testi qualificati” per assistere al matrimonio, dz. cyt., s. 62-64. Można mieć uzasadnione przypuszczenie, że w związku ze zmniejszającą się stale liczbą duchowieństwa i spadkiem powołań kapłańskich, Konferencje kolejnych krajów będą liczniej korzystały z tego uprawnienia. Ponadto warto pamiętać, że w 1999 roku Kongregacja Ewangelizacji Narodów i Krzewienia Wiary, wśród uprawnień specjalnych, realizowanych w Kościołach od niej bezpośrednio zależnych, otrzymała udzielanie pozwolenia biskupowi diecezjalnemu do delegowania świeckich jako świadków kwalifikowanych. Uprawnienie to, wraz z innymi zostało potwierdzone w roku 2005. Katalog ten znajduje się w: „Ius Missionale” 1(2007), s. 258-260.

${ }^{37}$ T. PAwluk, Forma zawarcia małżeństwa w świetle nowego Kodeksu Prawa Kanonicznego, dz. cyt., s. 50. W tym duchu wypowiada się także Stolica Apostolska w instrukcji „Ecclesiae de mysterio”, zauważając, że świecki może być delegowany jako świadek kwalifikowany, jedynie w przypadku wystąpienia prawdziwie ważnych okoliczności (vere singularibus), bądź w przypadku całkowitym braku świętych szafarzy. Por. Congregatio pro Clericis et Alliae, Instructio Ecclesiae de mysterio, de quidam questionibus circa fidelium laicorum cooperationem sacerdotum ministerium speciem, 15 augustii 1997, AAS 89 (1997), s. 873.

${ }^{38}$ Por. LG, n. 35.

${ }^{39}$ „Fidelem catholicum ad id muneris praestandum ipse per se eligat Ordinarius quavis exclusa delegatione". SAnCta Congregatione Pro Culto Divino, Instructio Sacramentalem indolem, 15 maii 1974, w: Enchiridion Vaticanum. Documenti ufficiali della Santa Sede, t. 5, dz. cyt., n. 486. L. Sabbarese zauważa, że o ile, w myśl przepisu wykluczeni są z tego prawa wikariusze generalni (kan. $134 \$ 3$ ), o tyle przysługuje ono wszystkim zrównanym w prawie z biskupem diecezjalnym. Jednakże autor ten uważa, że biskup diecezjalny może udzielić specjalnego mandatu wikariuszowi generalnemu lub biskupiemu, na mocy którego także oni mogliby 
Po trzecie, przed udzieleniem takiej delegacji biskup diecezjalny powinien uzyskać pozytywną opinię Konferencji Biskupów oraz zezwolenie Stolicy Apostolskiej (por. kan. $1112 \$ 1)^{40}$.

Również od strony samego delegowanego muszą zostać spełnione odpowiednie warunki, które prawodawca stawia $\mathrm{w} \$ 2$ analizowanego kanonu. Chodzi tu nie tylko o jurydyczną habilitas, o której mowa w kan. $228 \$ 1 \mathrm{KPK}$, ale także kwalifikacje, które są konieczne w wypełnieniu tego konkretnego obowiązku (in casu) ${ }^{41}$.

Według zawartych w nim określeń należy wybrać „odpowiedniego świeckiego, który potrafi przygotować nupturientów i właściwie odprawić liturgię zawierania małżeństwa”.

Ustawodawca używając określenia „odpowiedni” w stosunku do świeckiego, którego należy delegować, ma na myśli takie osoby, co do których można mieć przekonanie, że „(..) dobrze wypełnią powierzone im zadania”"2. Wspomniana „Instrukcja” z grudnia 1971 roku wprost wymienia kategorie osób, które mogą spełniać takie kryteria. Są to: kandydaci do święceń, alumni seminariów, katecheci, członkowie Akcji Katolickiej ${ }^{43}$. Oczywiście nie jest to katalog zamknięty, stąd też mogą to być także osoby konsekrowane czy też członkowie innych ruchów i stowarzyszeń katolickich. Istotne jest to, by były to osoby, „(...) które zgodnie z powszechnym przekonaniem są dojrzałe" ${ }^{4}$. Osoby takie powinny więc cieszyć się szacunkiem, być

delegować wiernych świeckich, jako świadków kwalifikowanych małżeństwa. Por. L. SABBARESE, I laici "testi qualificati” per assistere al matrimonio, dz. cyt., s. 57.

${ }^{40}$ Wymóg uzyskania pozytywnej opinii Konferencji Biskupów został przeniesiony ze wspomnianej wyżej przedkodeksowej instrukcji „Sacramentalem indolem” (n. 1), regulującej kwestię delegowania świeckich. Jednak nawet pomimo uzyskania negatywnej opinii Konferencji Biskupów, biskup diecezjalny może zwrócić się do Stolicy Apostolskiej o zezwolenie na delegację, której ta może udzielić. Por. U. NAVArReTE, Questioni sulla forma canonica ordinaria nei Codici latino e orientale, Periodica 85 (1996), s. 506-507.

${ }^{41}$ Por. L. SAbbarese, I laici „testi qualificati” per assistere al matrimonio, dz. cyt., s. 59.

${ }^{42}$ E. Sztafrowski (red.), Posoborowe prawodawstwo kościelne, dz. cyt., s. 367.

${ }^{43}$ Por. Tamże.

${ }^{44}$ Tamże. 
przygotowane do pełnionej roli, nie powinny mieć żadnego osobistego interesu w wyznaczonej funkcji ${ }^{45}$.

Tam, gdzie do asystowania zawarciu małżeństwa został delegowany wierny świecki, jego obecność nie jest fakultatywna. Jego funkcja wiąże się bowiem z przygotowaniem nupturientów do ślubu, przewodniczeniem obrzędom liturgicznym oraz sporządzeniem dokumentu zawarcia małżeństwa i odnotowaniem tego faktu w księgach parafialnych ${ }^{46}$. Delegowany świecki powinien także zadbać, by zostały dopełnione formalności wymagane przez prawo cywilne danego kraju, które zwyczajowo zachowuje się, gdy małżeństwo jest zawierane w obecności duchownych, jako świadków kwalifikowanych występujących z urzędu, bądź też delegowanych ${ }^{47}$.

Szczegółowe obowiązki powinien określić indult Stolicy Apostolskiej zezwalający na asystowanie i instrukcja delegującego biskupa diecezjalnego ${ }^{48}$.

Inaczej niż w przypadku delegowanego duchownego, do uprawnień delegowanego świeckiego nie należy władza dyspensowania od przeszkód małżeńskich, ponieważ nie występuje on jako minister sacer (por. kan. $1079 \$ 2$ ).

$\mathrm{Na}$ ratio legis, jakie przyświecało ustawodawcy przy wprowadzaniu przepisu pozwalającego na delegowanie osoby świeckiej do asystowania przy zawarciu małżeństwa, złożyło się kilka okoliczności. Jedną z nich było zaradzenie sytuacjom, w których wierni nie zawsze są usatysfakcjonowani formą nadzwyczajną zawarcia małżeństwa

\footnotetext{
${ }^{45}$ Por. Sancta Congregatione pro Culto Divino, Instructio Sacramentalem indolem, dz. cyt., s. 298-299.

${ }^{46} \mathrm{~W}$ odniesieniu do zapisu o właściwym odprawieniu liturgii sakramentu, warto zwrócić uwagę, że wierni powinni przyjmować sakramenty według rytu Kościoła sui iuris do którego należą. Kan. $112 \$ 2$ KPK przypomina, że „nawet długotrwały zwyczaj przyjmowania sakramentów według obrzędów Kościoła innego samodzielnego obrządku, nie pociąga za sobą przynależności do tego Kościoła”.

${ }^{47}$ Por. Sancta Congregatione pro Culto Divino, Instructio Sacramentalem indolem, dz. cyt., s. 298-299.

${ }^{48}$ Por. T. PAwluk, Forma zawarcia małżeństwa $w$ świetle nowego Kodeksu Prawa Kanonicznego, dz. cyt., s. 49.
} 
tylko wobec świadków zwykłych, uważając, że ważne jest tylko małżeństwo przy udziale świadka kwalifikowanego i przy zachowaniu obrzędów liturgicznych. Nierzadko zdarza się także, że wierni nie są świadomi istnienia formy nadzwyczajnej. Inną przyczyną była chęć uporządkowania sytuacji, w których małżeństwa zawierane w formie nadzwyczajnej są poza kontrolą Kościoła ${ }^{49}$.

Możliwość przewidziana w prawodawstwie zachodnim, delegowania świeckiego jako świadka kanonicznego, współbrzmi z kan. 129 $\$ 2 \mathrm{KPK}$, który przewiduje współdziałanie świeckich w sprawowaniu władzy rządzenia: „zgodnie z przepisami prawa”. Samo urzędowe asystowanie przy zawarciu małżeństwa nie jest ściśle związane z władzą jurysdykcyjną i władzą święceń, stąd też możliwość asystowania osoby świeckiej nie jest sprzeczna z przepisem kan. 274 KPK. Nie zawiera ona bowiem żadnego aspektu władzy rządzenia czy wykonywania jurysdykcji, nawet jeśli regulowana jest przez te same normy, które do nich się odnoszą ${ }^{50}$.

\subsection{Możliwość subdelegacji}

Udzielona delegacja może zostać pod pewnymi warunkami przekazana kolejnej osobie. Subdelegacja, bo z taką instytucją będziemy tu mieli do czynienia, jest możliwa w przypadku, w którym delegacja została udzielona duchownemu w formie ogólnej, na przykład do błogosławienia małżeństw zawieranych w danej parafii. Tak delegowany może w poszczególnych przypadkach własną powagą subdelegować tę władzę innemu kapłanowi czy też diakonowi (por. kan. 137 \$ KPK). Jednakże subdelegacja będzie dotyczyć konkretnego małżeństwa, nie zaś małżeństw jako takich, zawieranych w danej parafii. A zatem nie może subdelegować własnej delegacji ogólnej (por. kan. $137 \$ 3 \mathrm{KPK}$ ).

Jeśli dany kapłan został przez ordynariusza miejsca lub proboszcza upoważniony do asystowania przy zawieraniu poszczególnego małżeństwa, nie może subdelegować, nawet w przypadkach losowych,

\footnotetext{
${ }^{49}$ Por. Tamże, s. 49.

${ }^{50}$ Por. A. Авате, Il matrimonio nella nuova legislazione canonica, Roma-Brescia 1984, s. 148.
} 
tej delegacji innemu duchownemu, chyba że delegujący go ordynariusz lub proboszcz w delegacji na to zezwolił. Subdelegacja delegacji specjalnej bez zezwolenia delegującego jest nieważna (por. kan. 137 $\S 3 \mathrm{KPK})$.

Ten, komu władza została subdelegowana, nie może ponownie subdelegować władzy asystencji, chyba że delegujący wyraźnie na to zezwolił (por. kan. $137 \$ 4$ ). Nie możliwe jest zatem przekazanie własnej subdelegacji kolejnej osobie.

Aby było to możliwe, ten, kto delegował diakona lub kapłana do asystowania i błogosławienia określonego małżeństwa, musiałby, jeśli uznałby to za słuszne, zezwolić mu nie tylko na subdelegację innego duchownego, ale także na prawo kolejnej subdelegacji, dokonanej przez już subdelegowanego. W takim przypadku mielibyśmy do czynienia z prawem podwójnego subdelegowania ${ }^{51}$.

Jeśli, jak to zostało zaznaczone wcześniej, wikariusz otrzymałby w dekrecie od ordynariusza miejsca ogólną delegację do asystowania i błogosławienia małżeństw, mógłby na tej podstawie subdelegować do asystowania w poszczególnym przypadku innego duchownego. Nie mógłby jednak upoważnić subdelegowanego do przekazania tej władzy kolejnemu duchownemu. Inaczej rzecz miałaby się w odniesieniu do proboszcza tego wikariusza, który mógłby go upoważnić do subdelegowania z prawem kolejnej subdelegacji, gdyż posiada on zwyczajną, a nie delegowaną władzę do występowania jako świadek kwalifikowany przy zawieraniu małżeństw ${ }^{52}$. Gdy świadkiem kwalifikowanym, na mocy delegacji ogólnej, jest wierny świecki, niemożliwe jest udzielenie przez niego subdelegacji innej osobie ${ }^{53}$. Subdelegacja, jak również jej dalsze przekazanie może dokonać się zarówno w formie ustnej, jak i pisemnej.

\footnotetext{
${ }^{51}$ Por. T. PAw luk, Forma zawarcia małżeństwa w świetle nowego Kodeksu Prawa Kanonicznego, dz. cyt., s. 50.

${ }^{52}$ Por. Tamże, s. 51.

${ }^{53}$ Kongregacja Kultu Bożego i Dyscypliny Sakramentów wskazuje na to w reskrypcie, który nie zawiera klauzuli nisi aliud Episcopus dioecesanus providebit. Por., Rescriptum z 4.03.2000, Prot. N. 440/00.
} 


\section{4. Świadkowie zwykli}

Obok świadka kwalifikowanego, którego czynna obecność polega na odebraniu od nupturientów zgody małżeńskiej w imieniu Kościoła, w czasie celebracji zawierania małżeństwa kanonicznego w formie zwyczajnej, wymagana jest obecność dwóch świadków zwykłych ${ }^{54}$, których zadaniem jest potwierdzenie faktu zawarcia małżeństwa.

W związku z rolą, jaką świadkowie mają do spełnienia, prawodawca nie stawia im wygórowanych wymogów, właściwe nawet ich nie precyzując, wymagając jedynie ich obecności w momencie zawarcia małżeństwa (por. kan. $1108 \$ 1 \mathrm{KPK}$ ).

Świadkiem zwykłym może być więc każdy, kto jest zdolny dać wiarygodne świadectwo o zwarciu umowy małżeńskiej ${ }^{55}$. „Dlatego zgodnie z przyjętą przez klasycznych autorów, jak Sanchez, Gasparri, czy Cappello, nie żąda się od nich niczego poza tym, co wynika z natury rzeczy, ażeby mogli świadczyć o tym, co się dokonało"56.

Funkcję świadka zwykłego wypełnia ważnie zatem zarówno kobieta, jak i mężczyzna ${ }^{57}$, osoba ochrzczona, jak i nieochrzczona, wie-

\footnotetext{
${ }^{54}$ Poprzedni Kodeks z 1917 roku, w kan. 1094 żądał, aby przy zawieraniu małżeństwa było obecnych przynajmniej dwóch świadków zwykłych. Kodeks obowiązujący wymaga obecności tylko dwóch świadków zwykłych. Jednak w niebezpieczeństwie śmierci świadek kwalifikowany, na podstawie przysługującej mu władzy dyspensowania od formy kanonicznej, zgodnie z przepisem kan. $1079 \$ 1-2$, może asystować przy ślubie tylko w obecności jednego świadka zwykłego, a nawet gdyby zaszła konieczność bez świadków zwykłych. Por. T. PAwluk, Prawo kanoniczne według Kodeksu Jana Pawła II, t. 3, Olsztyn 1996, s. 184.

${ }^{55}$ Por. W. Góralski, Dyspensa od formy zawarcia małżństwa $w$ świetle nowego Kodeksu Prawa Kanonicznego, Prawo Kanoniczne 31 (1988) n. 1-2, s. 88.

${ }^{56}$ Por. M. Żurowski, Kanoniczne prawo małżeńskie Kościoła katolickiego, Katowice 1987, s. 297. Są więc nieporozumieniem żądania, z jakimi można spotkać się ze strony niektórych duszpasterzy, którzy od świadków zwykłych wymagają odpowiedniego wieku, płci, świadectwa praktykowania wiary, a nawet obowiązku przystąpienia do sakramentu pokuty przed wypełnieniem swojego zadania. Niekiedy wymagania te upodabniają się do tych, stawianych kandydatom na chrzestnych, których obowiązki są zupełnie inne w odniesieniu do wypełnianej funkcji (por. kan. 872-874 KPK).

${ }^{57}$ Mogą występować razem dwie kobiety lub dwóch mężczyzn.
} 
rzący lub niewierzący, katolik, akatolik ${ }^{58}$ lub wyznawca innej religii. Można jednak spotkać w ustawodawstwie partykularnym przepisy precyzujące stosowanie norm powszechnych w tym zakresie ${ }^{59}$.

Prawo kanoniczne również nie stawia wymagań co do wieku świadka zwykłego, nie wymaga jego pełnoletności. Jednakże gdy małżeństwo zawierane jest w formie wyznaniowej ze skutkami cywilnymi, czyli tzw. małżeństwo konkordatowe, przepisy polskie wymagają, aby zaświadczenie o zawarciu małżeństwa podpisali: „duchowny,

${ }^{58}$ „Osoba należąca do Kościoła wschodniego może być świadkiem małżeństwa w kościele katolickim. Również osoba należąca do Kościoła katolickiego może być świadkiem małżeństwa sprawowanego zgodnie z regułami w Kościele wschodnim. We wszystkich tych przypadkach sposób ich postępowania powinien być zgodny z ogólną dyscypliną dwóch zainteresowanych Kościołów, dotyczącą zasad udziału w takich małżeństwach". PAPIESKa RADA DS. POPIERANIA JEDNOścI CHRZEŚcIJAN, Dyrektorium w sprawie realizacji zasad i norm dotyczacych ekumenizmu, 25 marca 1993, http://analizy.biz/apologetyka/index.php option=com_content\&task=catego ry\&sectionid=46\&id=127\&itemid=96.htm (dostęp 7.08.2019), nr 128.

${ }^{59}$ Kwestię wymogów dla świadków normuje np. Konferencja Episkopatu Polski w Dekrecie ogólnym o przeprowadzeniu rozmów kanoniczno-duszpasterskich $z$ narzeczonymi przed zawarciem małżństwa kanonicznego z dnia 8 października 2019 r., którego art. 110 brzmi: „Z zasady świadkami zawarcia małżeństwa (kan. 1108 $\$ 1$ ) winni być katolicy. Należy ich zachęcić, o ile to możliwe, do odbycia spowiedzi i przystąpienia do Eucharystii. Ich obecność nie jest bowiem jedynie warunkiem ważności małżeństwa kanonicznego, ale są oni także reprezentantami wspólnoty wierzących, która za ich pośrednictwem uczestniczy w sakramentalnym akcie odnoszącym się do tej wspólnoty. Przy zawarciu małżeństwa mieszanego jednym ze świadków może być ochrzczony niekatolik. Jeśli zawierane jest małżeństwo konkordatowe, świadkowie winni być pełnoletni” Konferencja EpisKopatu Polski, Dekret ogólny Konferencji Episkopatu Polski o przeprowadzaniu rozmów kanoniczno-duszpasterskich z narzeczonymi przed zawarciem małzeństwa kanonicznego, https:// drive.google.com/file/d/1wThswscgcHj2tePTSOrAOLXS4GPYC5Yg/view (dostęp 17.01.2020). Przepisy te weszły w życie 1 czerwca 2020 r. Także we wcześniejszym dekrecie ogólnym, dotyczącym wystąpień z Kościoła oraz powrotu do jego wspólnoty Konferencja Episkopatu Polski postanawia, że osoba, która złożyła oświadczenie woli o wystąpieniu z Kościoła, nie może pełnić świadka zawarcia małżeństwa. Por., Konferencja Episkopatu Polski, Dekret ogólny w sprawie wystąpienia z Kościoła oraz powrotu do wspólnoty Koscioła, 7.10.2015, https:/episkopat.pl/wp-content/ uploads/2016/04/dekret_ogolny.pdf (dostęp 11.06.2020), art. 3, pkt. 4b. 
małżonkowie i dwaj pełnoletni świadkowie" (art. $8 \$ 2$ Kodeksu rodzinnego i opiekuńczego).

Chociaż więc przepisy Kodeksu Prawa Kanonicznego nie wymagają wprost odpowiedniego wieku, biorąc jednak pod uwagę wzgląd duszpasterski, wypada, aby osoba będąca świadkiem miała ukończony 14 rok życia (por. kan. $1550 \$ 1 \mathrm{KPK})^{60}$. Nie ma jednakże bezwzględnego zakazu powoływania osób małoletnich. Do godziwości wymaga się jednak, aby świadkami były osoby dorosłe, pozbawione zarzutów moralnych, czego domaga się świętość sakramentu małżeństwa ${ }^{61}$.

Co istotne, ważne, by były one jednocześnie obecne w miejscu zawarcia małżeństwa z nupturientami i świadkiem kwalifikowanym (ad validitatem), zdolne do rozpoznania osób zawierających małżeństwo oraz świadome tego, w czym uczestniczą, o jaki akt prawny chodzi i w razie potrzeby były w stanie o nim zaświadczyć. Stąd też z natury rzeczy wykluczone będą dzieci, nie posiadające jeszcze używania rozumu (por. kan. $97 \$ 2 \mathrm{KPK}$ ).

Podobnie jako osoby, które nie są całkowicie świadome, w jakim akcie prawnym uczestniczą, z powoływania do funkcji świadka zwykłego wyłączone będą osoby upośledzone umysłowo, upojone alkoholowo lub odurzone środkami psychoaktywnymi. Nie spełniają oni bowiem wymagań, którymi powinny odznaczać się zwykli świadkowie zawarcia małżeństwa ${ }^{62}$.

Aby świadkowie mogli ważnie wypełniać swoje zdania, nie jest konieczne, by zostali oni bezpośrednio wyznaczeni przez samych nupturientów, chociaż będzie to oczywiście sytuacja naturalna i najczęściej spotykana. Nie musi ich także w sytuacji nadzwyczajnej wyznaczać świadek kwalifikowany. Wystarczy ich faktyczna, nawet przypadkowa obecność w miejscu zawarcia małżeństwo i świadomość, w jakim wydarzeniu uczestniczą. Formalne wyznaczenie nie

\footnotetext{
${ }^{60}$ Kan. $1550 \$ 1 \mathrm{KPK}$, odnoszący się do świadków w procesie sądowym, nie pozwala powoływać do zeznań małoletnich poniżej 14 roku życia, chyba że istnieje uzasadniona ku temu przyczyna.

${ }^{61}$ Por. P.M. Gajda, Prawo małżeńskie Kościoła katolickiego, Tarnów 2005, s. 170.

${ }^{62}$ Por. J. Hendriks, Matrimonii forma extraordinaria, Periodica 84 (1995), s. 698.
} 
jest konieczne, podobnie jak nie wymaga się, aby mieli oni specjalną intencję spełniania swej funkcji. Zdolnymi do niej będą nawet osoby, które zostałyby zmuszone do uczestniczenia w ceremonii ślubu ${ }^{63}$.

Nazwiska świadków zwykłych zapisuje się w księdze małżeństw, składają oni również podpisy w akcie małżeństwa.

\section{Znaczenie formy kanonicznej}

Zachowanie formy kanonicznej małżeństwa stanowi warunek jego ważnego zawarcia. Wprowadzenie jej przez Sobór Trydencki miało przede wszystkim za zadanie zapobieżenie zawieraniu małżeństw nieważnych, bez udziału kapłana oraz małżeństw bigamicznych ${ }^{64}$.

Także dzisiaj forma kanoniczna ma pomagać w sprawowaniu władzy jurysdykcyjnej nad małżeństwem. Dzisiaj nikt już nie kwestionuje samej władzy Kościoła do ustanawiania formy kanoniczne ad validitatem $^{65}$. Dyskutowana jest wciąż natomiast zasadność utrzymywania jej wymogu do ważności małżeństwa, w dobie publicznego charakteru jego zawierania, jak i przede wszystkim rejestracji małżeństw na forum publicznym ${ }^{66}$. Współczesne państwa skutecznie bowiem wypełniają obowiązek cywilnej rejestracji małżeństw ${ }^{67}$.

\footnotetext{
${ }^{63}$ Por. L. Chiapetta, Il codice di diritto canonico, t. 2, Napoli 1988, s. 236.

${ }^{64}$ Por. P. Majer, Znaczenie kanonicznej formy zawarcia małżeństwa, dz. cyt., s. 142.

${ }^{65}$ Głosy kwestionujące wymóg formy kanonicznej do ważności małżeństwa pojawiały się na samym soborze trydenckim (por. L. BENDER, Forma iuridica celebrationis matrimonii. Commentarius in canones 1094-1099, Romae 1960, s. 17). Również głosy niektórych biskupów nadsyłane w fazie przygotowawczej do Soboru Watykańskiego II dotyczyły zasadności formy kanonicznej w odniesieniu do ważności małżeństwa. Podobnie temat ten był obecny w czasie prac rewizyjnych kodeksu. Por. M.A. Ortiz, La forma del matrimonio nella giurisprudenza della Rota Romana, w: La giurisprudenza della Rota Romana sul matrimonio (1908-2008), Studi Giuridici, t. 87, Città del Vaticano 2010, s. 274.

${ }^{66}$ Syntetyczne ujęcie stanowisk kanonistów w tej kwestii prezentuje: F.R. AznAR GiL, Derecho matrimonial canónico, t. 3: Canones 1108-1165, Salamanca 2003, s. 24-28.

${ }^{67}$ Por. P. MAJER, Znaczenie kanonicznej formy zawarcia małżeństwa, dz. cyt., s. 144.
} 
Joan Carreras zwraca jednak uwagę, że małżeństwo nie jest ani aktem publicznym, ani aktem prywatnym, lecz aktem osoby, podejmowanym zarówno prywatnie, jak i publicznie jednocześnie. Małżeństwo, jako osobisty akt poszczególnego kontrahenta, w oczywisty i konieczny sposób angażuje wspólnotę, posiadając także wymiar społeczny, z tego też powodu nie powinno być celebrowane $\mathrm{w}$ formie prywatnej lub też bez udziału kapłana (rozumiane jako matrimonium clandestinum $)^{68}$.

Zachowanie formy kanonicznej ad validitatem wynika z chęci zagwarantowania pewności prawnej, prawidłowego wykonywania prawa ius connubii w formie celebracji publicznej oraz zachowania komunii kościelnej, które polega także na posłuszeństwie wiernych władzy kościelnej, która komunikuje nupturientom, jakie warunki winni spełniać, aby ich małżeństwo było zawarte ważnie oraz potwierdza sam fakt jego zawarcia ${ }^{69}$.

Jak zauważa Piotr Majer: „Kanoniczna forma małżeństwa jest swoistym zapewnieniem Kościoła o integralności zgody małżeńskiej wyrażanej przez nowożeńców. Dopuszczając do obrzędu zawarcia małżeństwa, Kościół potwierdza, że konsens, jaki wyrażają, odpowiada autentycznemu wzajemnemu oddaniu się mężczyzny i kobiety, którzy zawierają małżeństwo"70.

\section{Wymóg zastosowania formy kanonicznej}

Kanoniczna forma zawarcia małżeństwa obowiązuje wówczas, gdy przynajmniej jeden z kontrahentów został ochrzczony w Kościele katolickim lub został do niego przyjęty, jak chce tego zreformowany w 2009 r. kan. 1117 KPK.

\footnotetext{
${ }^{68}$ Nie są to w tym kontekście małżeństwa zawierane w sposób tajny, w znaczeniu dzisiejszego kan. $1131 \mathrm{KPK}$, ale małżeństwa bez zachowania formy kanonicznej, czyli przede wszystkim bez udziału kapłana. Por. J. Carreras, Las bodas: sexo, fiesta y derecho, Madrid 1998, s. 130-131.

${ }^{69}$ M.A. OrTiz, La forma del matrimonio nella giurisprudenza della Rota Romana, dz. cyt., s. 279.

${ }^{70}$ P. MAJER, Znaczenie kanonicznej formy zawarcia małżeństwa, dz. cyt., s. 149.
} 
Za takim brzmieniem normy stoją przede wszystkim racje prawne, które kierowały ustawodawcą wymagającym formy kanonicznej zawarcia małżeństwa do jego ważności. Podczas gdy wady konsensu dotyczące zdolności i intencji są rozpatrywane na forum wewnętrznym zainteresowanego kontrahenta, forma zawarcia małżeństwa dotyczy kwestii zewnętrznych i społecznych w obszarze porządku prawnego. Jak zauważa Carmela De Franciscis, w przypadku małżeństwa kanonicznego, mogącego wywołać skutki cywilne, mamy do czynienia ze swoistym paradoksem. $Z$ jednej bowiem strony mówimy o bardzo osobistej czynności prawnej, o charakterze prywatnym, dotykającej samej natury człowieka, z drugiej jednak jest to czynność maksymalnie publiczna w odniesieniu do relacji państwo - Kościół, która będąc taką, przenosi nas z porządku prawa kościelnego do porządku prawa państwowego, angażując oba $\mathrm{z}$ nich ${ }^{71}$.

Forma kanoniczna jest więc wymagana, ponieważ jest zewnętrznym przejawem zawarcia małżeństwa - czynności prawnej, której samą istotą jest konsens między dwoma osobami.

W odniesieniu do małżeństwa sakramentalnego forma kanoniczna manifestuje, że sakrament ten jest nie tylko osobistą relacją małżonków z Bogiem, ale także widzialnym znakiem, który poprzez zewnętrzne oznaki formalne przekazuje łaskę sakramentu. Zewnętrzna celebracja sakramentu małżeństwa ma także szczególne uzasadnienie w tym, że w porównaniu z innymi sakramentami, które dokonują się wobec jednostki, małżeństwo niesie zbawienie dla dwóch osób poprzez jednoczesne trwanie w małżeńskiej wspólnocie, stąd też domaga się bardziej niż inne sakramenty publicznego charakteru jego sprawowania. Wraz z sakramentem małżeństwa zmienia się ponadto stan kanoniczny osoby, która go zawiera, a jednocześnie ta zmiana wywołuje skutki w społeczności, w której się to dokonuje. Tak więc,

\footnotetext{
${ }^{71}$ Por. C. De Franciscis, La forma nel matrimonio canonico, dz. cyt., s. 205; IoANnes Paulus II, Allocutio ad S.R. Rotae Tribunalis Praelatos Auditores, Officiales et Advocatos coram admissos, 28.01.1982, AAS 74 (1982), s. 451; DEC. C. STANKIEwiCz, 15.12.1992, RRDec., t. 84, s. 664-679.
} 
skutki sakramentu małżeństwa nie tylko dotykają prywatnej sfery małżonków, ale także sfery społecznej ${ }^{72}$.

Publiczny charakter formy zawarcia małżeństwa sakramentalnego odnosi się także do charakteru samego sakramentu, który przynosi zdaniem C. Franciscis swego rodzaju dojrzałość chrześcijańską małżonków, którzy poprzez sakrament otrzymują „szczególną legitymację", którą jest status, wyrażony łacińskimi terminami: consors, maritus, uxor. Kanoniczna forma zawarcia małżeństwa jest zatem zewnętrzną manifestacją wewnętrznej intencji go zawierających ${ }^{73}$.

Jak zauważa Piotr Kroczek, forma zawarcia małżeństwa, dokonująca się zgodnie z prawem kanonicznym, które jest tutaj pernecessarium instrumentum, niesie małżonkom możliwość życia w łasce, korzystania ze zbawczych owoców i praw przysługujących katolickim małżonkom. Prawo wymaga jednak pewnego stopnia ich wiedzy i świadomości w tym zakresie, który jednak, jak zauważa ten kanonista, nie jest konieczny do bycia katolikiem. W efekcie mogą się pojawiać ograniczenia w dopuszczaniu katolików do zawarcia sakramentu małżeństwa. W takim znaczeniu prawo kanoniczne niekiedy pozbawia dostępu do łaski sakramentu ${ }^{74}$. Jest to jednak przejawem wypełniania przez władzę kościelną obowiązku ochrony dobra, jakim jest sakrament, za pomocą normy prawnej. Wymóg obowiązku zachowania przez katolików formy kanonicznej zawarcia małżeństwa nie może być jednak rozumiany jako nadużycie władzy, choć niekiedy stosowanie norm dotyczących obligatoryjnej formy małżeństwa może stać się nieuzasadnioną przyczyną trudności w dostępie do łaski sakramentu. Wymóg formy ad validitatem, co było wzmiankowane już wyżej, może jawić się jako niezgodny z principium prawa kanonicznego, którym jest salus animarum. Można stwierdzić, że normy

\footnotetext{
${ }^{72}$ Por. C. De Franciscis, La forma nel matrimonio canonico, dz. cyt., s. 205.

${ }^{73}$ Por. Tamże.

${ }^{74}$ Przykładem tego jest wymierzenie kary cenzury, która nie pozwala przyjmować sakramentów (por. kan. $1331 \S 1$, n. 2; kan. 1332 KPK).
} 
te przyczyniają się do wzrostu małżeństw nieważnych, bez żadnych korzyści duchowych dla nupturientów ${ }^{75}$.

Przywołany wyżej kanonista zwraca uwagę, że wymóg obowiązkowego zachowania formy kanonicznej małżeństwa może prowadzić do niewłaściwego jej użycia, co niesie ze sobą kanoniczne konsekwencje i przyczynia się do niewłaściwego rozumienia przymiotu nierozerwalności małżeństwa. Jednym z tego przykładów może być cyniczne traktowanie przez katolika wymogu formy jako carte blanche, udzielonej od Kościoła w celu zawierania małżeństwa poza Kościołem, uchylając się od formy kanonicznej, wiedząc, że nie będzie ono węzłem uznawanym przez Kościół za ważny na forum kanonicznym. To nie sprzyja duchowemu pożytkowi wiernych. Ci, którzy będą chcieli być posłuszeni prawu, w niektórych przypadkach będą musieli prowadzić proces o stwierdzenie nieważności małżeństwa, inni, z powodu przeszkody węzła, będą skazani na życie bez możliwości korzystania z praw przysługujących małżonkom katolickim. Nieposłuszeństwo prawu ze strony lekceważących wymóg zachowania formy paradoksalnie może przynieść im korzyść. W przypadku zawarcia przez nich małżeństwa w innej formie, a następnie po jego rozpadzie, mają możliwość zawarcia nowego małżeństwa w formie kanonicznej. Zdaniem Piotra Kroczka, powołującego się na holenderskiego kanonistę Petera Huizinga, zniesienie wymogu zachowania formy kanonicznej usunęłoby powyższy problem ${ }^{76}$.

Drugim, powiązanym z wyżej omówionym przykładem niewłaściwego podejścia do wymogu formy jest zawieranie małżeństw ad experimentum. Jest to sytuacja pary, która umyślnie narusza prawo dotyczące formy, celowo zawierając małżeństwo w formie niekanonicznej. Jeśli tak zawarte małżeństwo okaże się udane, może zostać uważnione przez uzupełnienie formy. Jeśli natomiast okaże się niepowodzeniem, strony będą mogły zawrzeć nowe związki z innymi partnerami. W konsekwencji takiego postępowania wymóg zachowania

\footnotetext{
${ }^{75}$ Por. P. KRoczek, Does obligatory canonical from of marriage contribute to „salus animarum"?, Folia Canonica 12 (2009), s. 25-26.

${ }^{76}$ Por. Tamże, s. 26.
} 
formy może stać się środkiem do podjęcia życia małżeńskiego „na próbę”. Problem ten staje się dziś powszechny i nierzadko powoduje skandale we wspólnocie wierzących ${ }^{77}$.

W obu przywołanych wyżej sytuacjach obligatoryjny walor zachowania formy kanonicznej może być niesłusznie rozumiany jako forma akceptacji ze strony ustawodawcy konkubinatu bez kanonicznego sformalizowania. Może to być również przyczyną fałszywego wrażenia, jakoby prawodawca sprzyjał mentalności prorozwodowej ${ }^{78}$.

W tym miejscu wypada powrócić do wzmiankowanej wyżej reformy w obrębie kan. 1117 KPK. Dokonał jej Benedykt XVI przez motu proprio „Omnium in mentem”, usuwając z treści kanonu klauzulę „sit neque actu formali ab ea defecerit"79. A zatem uchylono postanowienie kan. 1117 KPK, mówiące że wiernych, którzy odstąpili od Kościoła „formalnym aktem”, nie obowiązują przepisy kościelne dotyczące kanonicznej formy małżeństwa. Racją dla wprowadzenia nowelizacji były liczne problemy duszpasterskie, które powodowało reformowane prawo. „Przede wszystkim trudne okazało się w poszczególnych wypadkach określenie i praktyczne sformułowanie wspomnianego „formalnego aktu odstąpienia” od Kościoła, zarówno pod względem jego istoty teologicznej, jak i samego aspektu kanonicznego. Ponadto wiele trudności zrodziło się zarówno w działalności „duszpasterskiej, jak i w praktyce sądów. Zauważano bowiem, że nowe prawo zdaje się stwarzać, przynajmniej pośrednio, pewne ułatwienie lub jakby bodziec do apostazji tam, gdzie liczba wiernych katolików jest niewielka albo obowiązują niesprawiedliwe prawa małżeńskie, dyskryminujące obywateli ze względów religijnych; ponadto utrudniało ono powrót osób ochrzczonych, które pragnęły gorąco zawrzeć nowe małżeństwo kanoniczne po rozpadzie poprzedniego; wreszcie, pomijając inne

\footnotetext{
77 Por. Tamże.

${ }^{78}$ Por. E. Dunderdale, The Canonical Form of Marriage: Anachronism or Pastoral Necessity?, Studia Canonica 12 (1978), s. 51.

79 Benedictus XVI, Litterae apostolicae motu proprio datae quaedam in Codice Iuris Canonici immutantur „Omnium in mentem”, AAS 102 (2010), s. 8 - 10. Tekst polski: „L'Osservatore Romano” (wyd. pol.) 5 (333) 2010, s. 13-14.
} 
sprawy, wiele z tych małżeństw de facto stawało się dla Kościoła tak zwanymi małżeństwami tajnymi (clandestina)" 80 .

Zdaniem Miguela A. Ortiza zniesienie klauzuli, dokonane reformą wprowadzoną przez omawiane motu proprio, chciało z jednej strony zapobiec niepewności dotyczącej tego, którzy wierni są w rzeczywistości zobowiązani do zachowania formy, a z drugiej uniknąć sytuacji, w których wielu z nich jest „uwięzionych” w małżeństwach ważnych, które się rozpadły. W ten sposób prawodawca chciał zagwarantować pewność i zapewnić możliwość do „rekonstrukcji” życia wiernych, którzy nie zachowując formy kanonicznej pozostawali „wolni” do zawarcia nowego małżeństwa, kiedy pierwsze, zawarte bez formy kanonicznej, uległo rozpadowi ${ }^{81}$.

Jak przekonuje wspomniany kanonista, motu proprio „Omnium in mente” wyraźnie odchodzi od poprzednich założeń: gwarancji pewności prawnej i otwarcia na uregulowanie sytuacji związków zawartych nieważnie z powodu braku formy. Jest prawdą, że wątpliwości co do interpretacji zawieszonej klauzuli powodowały szkody w rzeczywistości prawnej Kościoła, ale także jest prawdą, że znaczenie praktyczne klauzuli było zgodne z intuicjami soborowymi oraz kodeksowymi, według których należy sprawić, by wola zawarcia małżeństwa była rzeczywiście skuteczna, to znaczy zdolna do stworzenia węzła ${ }^{82}$.

Na koniec, celem konkluzji tej części opracowania, należy dodać, że osoby, które nie są zobowiązane do zachowania formy katolickiej, mogą zawierać małżeństwo w jakiejkolwiek formie, także przepisanej prawem świeckim. W odniesieniu do ochrzczonych akatolików będzie to zazwyczaj związek małżeński religijny, zawarty wobec duchownego swojego wyznania. Osoby nieochrzczone zobowiązane są do

\footnotetext{
${ }^{80}$ Por. Tamże, s. 13.

${ }^{81}$ Por. M.A. ORTIz, Questioni riguardanti la forma matrimoniale la „convalidazione invalida" e l'ambito di obbligatorietà dopo il m.p. "Omnium in mentem", w: H. Franceschi, M.A. Ortiz (red,.) La ricerca della verità sul matrimonio e il diritto a un processo giusto e celere. Temi di diritto matrimoniale e processuale canonico, Roma 2010, s. 197.

${ }^{82}$ Por. Tamże, s. 203-204.
} 
zawarcia małżeństwa w formie przewidzianej przez odnośne prawo państwowe ${ }^{83}$.

\section{Dyspensa}

Z brzmienia normy prawnej wysłowionej w kan. 1117 KPK jasno wynika, co starano się ukazać w niniejszej refleksji, że w przypadku małżeństwa strony katolickiej ze stroną akatolicką do ważności zawarcia małżeństwa forma prawna jest obowiązująca. Prawodawca przewidział jednak możliwość udzielenia od tego obowiązku dyspensy, o czym wzmiankuje w kan. $1127 \$ 2$ KPK.

D.J. Andres zwraca uwagę, że sam prawodawca przewiduje cztery wyjątki od zasady obowiązywalności formy. Pierwszy z nich dotyczy błędu powszechnego, faktycznego czy prawnego oraz wątpliwości pozytywnej i prawdopodobnej, w przypadku których, w myśl kan. 144 KPK, Kościół uzupełnia brak ważnej delegacji asystującego, o czym wspomniano wyżej. Drugim wyjątkiem jest delegowanie świeckich, po spełnieniu odpowiednich warunków, do urzędowego asystowania przy zawieraniu małżeństw. Trzecim przypadkiem jest zgoda ustawodawcy, aby przy zawieraniu małżeństw strony katolickiej z niekatolicką obrządku wschodniego forma kanoniczna wymagana była tylko do godziwości (por. kan. $1127 \$ 1 \mathrm{KPK}$ ). Wreszcie ostatnim wyjątkiem od reguły, stanowiącej zwyczajną formę zawarcia małżeństwa jako właściwą, jest dopuszczalność w wyżej określonych sytuacjach zastosowania formy nadzwyczajnej (por. kan. $1116 \$ 1 \mathrm{KPK})^{84}$.

W poszczególnych przypadkach, poza wymienionymi wyjątkami, udzielenie dyspensy od przepisu kan. $1108 \$ 1$ KPK prawodawca traktuje jako sytuację wyjątkową. Jak zauważa Wojciech Góralski, wskazuje na to sama ranga kodeksowej normy wyrażonej w wyżej wymienionym kanonie, który stoi na straży zawierania umowy małżeńskiej coram Ecclesia ${ }^{85}$.

\footnotetext{
${ }^{83}$ Por. W. Góralski, Kościelne prawo małżeńskie, Warszawa 2006, s. 199.

${ }^{84}$ Por. D.J. Andres, De dispensatione a forma canonica matrimonii, Apollinaris 58 (1985) nr 3-4, s. 443-444.

${ }^{85}$ Por. W. GóRAlski, Studia nad małżeństwem i rodziną, Warszawa 2007, s. 460.
} 
W zwyczajnych warunkach od zachowania formy może zawsze dyspensować Stolica Apostolska. Prawodawca kodeksowy w trzech przypadkach do udzielenia takowej upoważnia również ordynariusza miejsca.

Pierwszym $\mathrm{z}$ nich jest niebezpieczeństwo śmierci, w którym zgodnie $\mathrm{z}$ kan. $1079 \$ 1$ KPK może on dyspensować swoich podwładnych gdziekolwiek przebywających oraz wszystkich przebywających na jego własnym terytorium. Drugi paragraf wymienionego kanonu rozszerza kompetencję do udzielenia dyspensy od formy w niebezpieczeństwie śmierci na proboszcza, kapłana i diakona delegowanych do asystowania przy zawieraniu umowy małżeńskiej oraz na kapłana i diakona, obecnych przy zawieraniu małżeństwa w takich okolicznościach $\mathrm{w}$ formie nadzwyczajnej. W tym ostatnim przypadku proboszcz, kapłan delegowany, bądź kapłan i diakon, gdyby byli obecni, mogą to uczynić, jeśli istnieje niemożność odniesienia się do ordynariusza miejsca (por. kan. $1079 \$ 2 \mathrm{KPK}$ ).

Drugim przypadkiem jest opisana w kan. $1127 \$ 2$ KPK dyspozycja w przypadku zawierania małżeństwa mieszanego. Udzielenie dyspensy od zachowania kanonicznej formy zawarcia małżeństwa w takim przypadku jest prawem ordynariusza miejsca, także wtedy, gdy jedna ze stron jest nie tylko akatolicka, ale nawet nieochrzczona. Przepis wyżej przywołanego kanonu wszedł do obowiązującego kodeksu jako konsekwencja udzielenia takiego uprawnienia przez papieża Pawła VI w motu proprio „Matrimonia mixta” z 31 marca $1970 \mathrm{r}^{86}$ Zgodnie z nim, gdy zawarcie kanonicznej formy małżeństwa jest poważnie utrudnione, ordynariusz miejsca strony katolickiej ma prawo w poszczególnych przypadkach od niej dyspensować, z zachowaniem jakiejś publicznej formy zawarcia umowy. Jest to warunek stawiany do ważności tak zawartego małżeństwa (por. kan. $1127 \$ 2 \mathrm{KPK}$ ).

Ważnym doprecyzowaniem w kwestii dyspensowania od formy przy małżeństwach mieszanych jest dyspozycja art. 11,

\footnotetext{
${ }^{86}$ Paulus VI, Litterae Apostolicae motu proprio datae Normae de matrimoniis mixtis, AAS 62 (1970), s. 257-263. Tekst polski: Prawo Kanoniczne 14 (1971), nr 3-4, s. 239-249.
} 
promulgowanego w 2016 roku, motu proprio „De concordia inter Codices" ${ }^{87}$, zmieniająca brzmienie paragrafu pierwszego kan. 1127 KPK, co ma swoje konsekwencje także w przypadku dyspensy ${ }^{88}$.

H. Stawniak zauważa, że w świetle obecnego stanu prawnego, ordynariusz miejsca łacinnik może dyspensować od formy kanonicznej na mocy kan. $1127 \$ 2$ KPK, w przypadku zawierania małżeństwa między katolikiem łacińskim i protestantem lub między katolikiem łacinnikiem i nieochrzczoną osobą. Natomiast w przypadku katolików wschodnich ta dyspensa, według kan. $835 \mathrm{KKKW}^{89}$, jest zarezerwowana Stolicy Apostolskiej lub Patriarsze. Ten ostatni może dyspensować tylko dla najpoważniejszej przyczyny. Zatem, jak konstatuje H. Stawniak, ordynariusz miejsca łacinnik nie mógłby dyspensować od formy kanonicznej w przypadku małżeństwa między katolikiem wschodnim, jemu poddanym, ze stroną protestancką lub nieochrzczoną ${ }^{90}$. Poważną trudnością do udzielenia dyspensy może okazać się zdecydowana odmowa strony niekatolickiej zawierania umowy małżeńskiej w formie kanonicznej ${ }^{91}$.

Na gruncie polskim, w odniesieniu do dyspensy w przypadku małżeństwa mieszanego, należy przywołać normy prawa partykularnego, które weszły w życie 1 czerwca 2020 roku. Wprowadza je wspomniany wcześniej „Dekret ogólny Konferencji Episkopatu Polski

\footnotetext{
${ }^{87}$ Franciscus, Litterae Apostolicae Motu Proprio Datae Quibus nonnullae normae Codicis Iuris Canonici immutantur, dz. cyt., s. 603, art. 11. Tekst polski: R. Kamiński, H, Stawniak (red.), Chrzest i małżeństwo. Harmonizacja ustawodawstwa, Warszawa 2018, s. 203, art. 11.

${ }^{88}$ Ta zmiana była podyktowana wprowadzeniem, przez to samo motu proprio, paragrafu 3 do kan. $1108 \mathrm{KPK}$ : „\$3. Solus sacerdos valide assistit matrimonio inter partes orientales vel inter partem latinam et partem orientalem sive catholicam sive non catholicam".

${ }^{89}$ Can. 835 CCEO: „Dispensatio a forma celebrationis matrimonii iure praescripta reservatur Sedi Apostolicae vel Patriarchae, qui eam ne concedat nisi gravissima de causa”.

${ }^{90}$ Por. H. Stawniak, Modyfikacje przepisów dotyczacych formy zawarcia małżeństwa wprowadzone przez papieża Franciszka, dz. cyt., s. 98.

${ }^{91}$ Por. W. Góralski, Studia nad małżenstwem i rodziną, dz. cyt., s. 452.
} 
o przeprowadzaniu rozmów kanoniczno-duszpasterskich z narzeczonymi przed zawarciem małżeństwa kanonicznego".

Wśród ważnych powodów, dla których ordynariusz miejsca strony katolickiej może, po zasięgnięciu opinii ordynariusza miejsca, w którym małżeństwo będzie zawierane, udzielić dyspensy, ustawodawca wskazuje zachowanie harmonii rodzinnej, uzyskanie zgody rodziców na małżeństwo, uznanie szczególnego zaangażowania religijnego strony niekatolickiej, bądź jej więź pokrewieństwa z szafarzem innego Kościoła lub Wspólnoty eklezjalnej (por art. 90). Jeśli nupturienci korzystają z dyspensy, aby ich małżeństwo było ważne winni zachować jakąś publiczną formę jego zawarcia. „Na pierwszym miejscu należy postawić zawarcie związku małżeńskiego we wspólnocie Kościoła lub Wspólnoty eklezjalnej strony niekatolickiej, jeśli zawarcie małżeństwa dokonuje się tam w formie publicznej i jest to rzeczywiście forma zawarcia małżeństwa $\mathrm{z}$ wyrażeniem zgody małżeńskiej, a nie inna ceremonia. W wyjątkowych i uzasadnionych poważną koniecznością przypadkach ordynariusz miejsca udzielający dyspensy może zgodzić się na zawarcie przez nupturientów małżeństwa w formie cywilnej" (art. 92).

Ostatnim przypadkiem, w którym do udzielenia dyspensy a forma canonica jest ordynariusz miejsca - a w tym konkretnym - biskup diecezjalny, jest uważnienie małżeństwa „w zawiązku”. Dzieje się tak, ponieważ, w myśl kan. $1161 \$ 1 \mathrm{KPK}$, instytucja ta polegająca na uważnieniu nieważnie zawartego małżeństwa, dokonanego przez kompetentną władzę, bez ponawiania zgody przez nupturientów, zawiera w sobie także udzielenie dyspensy od formy kanonicznej, gdyby ta nie została zachowana (por. także kan. $1165 \$ 2 \mathrm{KPK}$ ). Jest to integralna część uważnienia w zawiązku².

\footnotetext{
${ }^{92}$ Trzy wymienione przypadki władzy ordynariusza miejsca nie obejmują przypadku, kiedy to poza niebezpieczeństwem śmierci, należałoby udzielić dyspensy od formy kanonicznej, w małżeństwie zawieranym przez dwóch katolików. Wątpliwość co do takiej możliwości była przedmiotem pytania zadanego Papieskiej Komisji do Autentycznej Interpretacji Kodeksu z 14 maja 1985 roku. Negatywna odpowiedź Komisji, stwierdzająca, że w kan. $87 \$ 1$ KPK nie zawiera się władza biskupa diecezjalnego dyspensowania od formy dwojga katolików (poza niebezpieczeństwem
} 
Rzeczą zupełnie oczywistą jest zakaz zawierania dwóch typów jednego małżeństwa, korzystając z dwóch odrębnych form, np. jednej cywilnej, drugiej religijnej, czy też jednej „naturalnej”, drugiej sakramentalnej ${ }^{93}$. W przypadku małżeństw mieszanych nie jest dozwolone sprawowanie dwóch odrębnych obrzędów religijnych zawarcia małżeństwa (por. kan. $1127 \$ 3 \mathrm{KPK}$ ).

\section{Zakończenie}

W świetle obowiązujących norm kanoniczna forma zawarcia małżeństwa jest prawnym sposobem wyrażenia zgody małżeńskiej, aktu woli, który jest przyczyną sprawczą małżeństwa, zgodnie z zasadą matrimonium facit consensus. Dla aktu prawnego, jakim jest umowa małżeńska, forma jest więc elementem konstytutywnym, którego nie można traktować w kategoriach zwykłego formalizmu.

Z drugiej jednak strony nie brakuje w doktrynie głosów, które postulują zniesienie wymogu formy ad validitatem, zachowując do ważności jej publiczny charakter i wolę zawarcia małżeństwa jako znaku sakramentalnego, zgodnie z zamysłem Bożym. W dobie, kiedy obowiązek rejestracji małżeństw, w celu ochrony przed poligamią, jest w większości państw dobrze wypełniany za pomocą procedur cywilnych, zdaniem zwolenników tej opcji, forma kanoniczna jako wymóg do ważności małżeństwa nie jest już konieczna. Kontrola prawa cywilnego jest tu wystarczająca. To właśnie bowiem przeciwdziałanie nadużyciom w sferze zawierania wielu małżeństw oraz wypaczeniom, polegającym na zawieraniu ich w formie prywatnej, bez udziału kapłana (matriomonia clandestina), stało u podstaw ujednolicenia kanonicznej formy małżeństwa przez Sobór Trydencki w dekrecie Ne temere.

Także dzisiaj funkcja ochronna małżeństwa jako instytucji i dobra publicznego, angażującego zarówno strony zawierające konsens,

śmierci), potwierdziła wyjątkowość dyspensy od przepisu kan. $1108 \$ 1$ KPK. Szerzej na ten temat: W. GóRALSKI, Studia nad małżeństwem i rodzina, dz. cyt., s. 454-459.

${ }^{93}$ Por. M.A. ORTiz, La forma del matrimonio nella giurisprudenza della Rota Romana, dz. cyt., s. 278. 
jak i całą wspólnotę Kościoła i państwa, jest ratio legis istniejących przepisów dotyczących kanonicznej formy jego zawarcia.

Zwolennicy wprowadzenia wymogu formy ad liceitatem zwracają uwagę na to, że obecny obligatoryjny jej charakter, może służyć praktyce unikania zawierania małżeństwa w Kościele, aby w przypadku niepowodzenia, kolejny związek mógł być zawarty zgodnie z wymogami kanonicznymi. Stąd też zarzut tolerowania praktyki zawierania małżeństw ad experimentum i mentalności prorozwodowej.

Istotną zmianę w obrębie formy zawarcia małżeństwa przyniosło w 2009 roku motu proprio „Omnium in mentem”, usuwając z przepisu kan. 1117 KPK określenie dotyczące „formalnego aktu”, którym wierny odstępuje od Kościoła. Taki zapis „uwalniał” osoby po akcie apostazji od obowiązku zachowania kanonicznej formy zawarcia małżeństwa. Nowelizacja spowodowana była trudnością określenia w poszczególnych wypadkach wspomnianego „formalnego aktu odstąpienia" od Kościoła, zarówno pod względem jego istoty teologicznej, jak i samego aspektu kanonicznego. Inne trudności pojawiały się na gruncie duszpasterskim i w judykaturze sądów kościelnych. Były nimi apostazje dokonywane w miejscach, gdzie liczba wiernych jest niewielka albo też tam gdzie obowiązują niesprawiedliwe prawa małżeńskie, dyskryminujące obywateli ze względów religijnych. Dotychczasowy zapis kan. 1117 KPK powodował ponadto utrudnienie dla osób ochrzczonych, pragnących powrócić na łono Kościoła i zawrzeć nowe małżeństwo kanoniczne po rozpadzie poprzedniego.

Podstawową kanoniczną formą zawarcia małżeństwa pozostaje więc forma zwyczajna, której poświęcono niniejsze studium, a zatem zawarcie małżeństwa polegające na wyrażeniu przez strony zgody małżeńskiej wobec świadka kwalifikowanego bądź też jego delegata, (tam gdzie jest taka potrzeba i spełnione zostaną warunki stawiane przez prawodawcę, także wobec osoby świeckiej), oraz wobec dwóch świadków zwykłych.

Precyzyjne przepisy dotyczące możliwości asystowania świadka urzędowego, który nie tylko jest biernie obecny, ale przyjmuje zgodę małżeńską, mają zapobiec zawieraniu małżeństw nieważnych z powodu niezachowania formy kanonicznej. Chociaż nie ma wymogów 
stawianych wprost przez prawo powszechne świadkom zwykłym, prawo partykularne doprecyzowuje te wymagania.

Prawodawca przewiduje wyjątki od obowiązku zachowania zwyczajnej formy zawarcia małżeństwa jak: uzupełnienie braku ważnej delegacji asystującego, wspomniane wyżej delegowanie świeckich, czy też zgoda w przypadku małżeństw strony katolickiej z niekatolicką obrządku wschodniego, na zachowanie formy jedynie do godziwości. Wyjątkiem od reguły, jest także dopuszczalność, w określonych sytuacjach zastosowania formy nadzwyczajnej.

W poszczególnych przypadkach możliwe jest także uzyskanie dyspensy od obowiązku zachowania formy, udzielanej nupturientom w niebezpieczeństwie śmierci, w przypadku małżeństw mieszanych, czy też w ramach uważnienia małżeństwa w zawiązku.

Bez wątpienia należy skonkludować, że tak doniosła decyzja życiowa, podejmowana jako akt prawny - umowa małżeńska, zawierana według zamysłu Bożego wobec Kościoła, domaga się odpowiedniej, zgodnej z prawem formy, która zapewnia dokonania tego aktu w sposób nie tylko godny, ale nade wszystko ważny, skutkujący konsekwencjami w życiu jednostek go podejmujących i społeczności, w której się to dokonuje.

\section{The ordinary form of canonical marriage}

The marriage consent, which is the causative cause of marriage, in the light of applicable legislation, must be expressed in accordance with the law. The proper way to get married in the Catholic Church is through the ordinary form described in can. 1008-1114 CIC. The instructions contained therein refer to a qualified witness and ordinary witnesses to marry. These are the constitutive elements of this form of canonical marriage, to which the first part of the study was devoted. It is supplemented by considerations on the delegation of authorization to assist in getting marriage.

The following section describes the circumstances that necessitate the use of the canonical form and the circumstances justifying the dispensation from the obligation to maintain it. 
The provisions of positive law regarding form, by regulating this area of matrimonial law, protect marriage not only as a private good, but also as an institution of public good.

The canonical form of marriage, which cannot be treated in a broad way, at the same time cannot be just a „formality”, because its meaning in the ecclesial sense is deeper.

Established by the church authority, as a requirement ad validitatem matrimonii, it demands a public form for its conclusion, although the doctrine does not lack voices postulating the abolition of the obligatory nature of canonical form, which was also given attention in the article.

SŁOWA KLUCzowe: zwyczajna forma zawarcia małżeństwa; świadek kwalifikowany; świadek zwyczajny; delegacja; dyspensa

KEYWORDs: ordinary form of marriage; qualified witness; ordinary witness; delegation; dispensation

\section{Nota o AUTORZE}

Ks. DR RAFA£ KAMIŃski CSMA - doktor nauk prawnych w zakresie prawa kanonicznego, adiunkt w Katedrze Kanonicznego Prawa Małżeńskiego i Rodzinnego na Wydziale Prawa Kanonicznego Uniwersytetu Kardynała Stefana Wyszyńskiego w Warszawie, obrońca węzła małżeńskiego Sądu Metropolitalnego Warszawskiego. 